\title{
Cryptotephra from the Icelandic Veiðivötn 1477 CE eruption in a Greenland ice core: confirming the dating of volcanic events in the 1450s CE and assessing the eruption's climatic impact
}

\author{
Peter M. Abbott ${ }^{1}$, Gill Plunkett ${ }^{2}$, Christophe Corona ${ }^{3}$, Nathan J. Chellman ${ }^{4}$, Joseph R. McConnell ${ }^{4}$, John R. Pilcher ${ }^{2}$, \\ Markus Stoffel $^{5,6,7}$, and Michael Sigl ${ }^{1}$ \\ ${ }^{1}$ Climate and Environmental Physics and Oeschger Centre for Climate Change Research, \\ University of Bern, 3012 Bern, Switzerland \\ ${ }^{2}$ Archaeology and Palaeoecology, School of Natural and Built Environment, \\ Queen's University Belfast, Belfast BT7 1NN, UK \\ ${ }^{3}$ Geolab, Université Clermont Auvergne, CNRS, 63000, Clermont-Ferrand, France \\ ${ }^{4}$ Desert Research Institute, Nevada System of Higher Education, Reno, Nevada 89512, USA \\ ${ }^{5}$ Climatic Change Impacts and Risks in the Anthropocene (C-CIA), Institute for Environmental Sciences, \\ University of Geneva, 1205 Geneva, Switzerland \\ ${ }^{6}$ Department of Earth Sciences, University of Geneva, 1205 Geneva, Switzerland \\ ${ }^{7}$ Department F.-A. Forel for Environmental and Aquatic Sciences, University of Geneva, 1205 Geneva, Switzerland
}

Correspondence: Peter M. Abbott (peter.abbott@climate.unibe.ch)

Received: 31 July 2020 - Discussion started: 18 August 2020

Revised: 8 January 2021 - Accepted: 28 January 2021 - Published: 4 March 2021

\begin{abstract}
Volcanic eruptions are a key source of climatic variability, and reconstructing their past impact can improve our understanding of the operation of the climate system and increase the accuracy of future climate projections. Two annually resolved and independently dated palaeoarchives tree rings and polar ice cores - can be used in tandem to assess the timing, strength and climatic impact of volcanic eruptions over the past $\sim 2500$ years. The quantification of post-volcanic climate responses, however, has at times been hampered by differences between simulated and observed temperature responses that raised questions regarding the robustness of the chronologies of both archives. While many chronological mismatches have been resolved, the precise timing and climatic impact of two major sulfate-emitting volcanic eruptions during the $1450 \mathrm{~s} \mathrm{CE}$, including the largest atmospheric sulfate-loading event in the last 700 years, have not been constrained. Here we explore this issue through a combination of tephrochronological evidence and highresolution ice-core chemistry measurements from a Greenland ice core, the TUNU2013 record.
\end{abstract}

We identify tephra from the historically dated $1477 \mathrm{CE}$ eruption of the Icelandic Veiðivötn-Bárðarbunga volcanic system in direct association with a notable sulfate peak in TUNU2013 attributed to this event, confirming that this peak can be used as a reliable and precise time marker. Using seasonal cycles in several chemical elements and $1477 \mathrm{CE}$ as a fixed chronological point shows that ages of $1453 \mathrm{CE}$ and $1458 \mathrm{CE}$ can be attributed, with high precision, to the start of two other notable sulfate peaks. This confirms the accuracy of a recent Greenland ice-core chronology over the middle to late 15th century and corroborates the findings of recent volcanic reconstructions from Greenland and Antarctica. Overall, this implies that large-scale Northern Hemisphere climatic cooling affecting tree-ring growth in $1453 \mathrm{CE}$ was caused by a Northern Hemisphere volcanic eruption in 1452 or early $1453 \mathrm{CE}$, and then a Southern Hemisphere eruption, previously assumed to have triggered the cooling, occurred later in 1457 or $1458 \mathrm{CE}$.

The direct attribution of the $1477 \mathrm{CE}$ sulfate peak to the eruption of Veiðivötn, one of the most explosive from Iceland in the last 1200 years, also provides the opportunity to 
assess the eruption's climatic impact. A tree-ring-based reconstruction of Northern Hemisphere summer temperatures shows a cooling in the aftermath of the eruption of $-0.35^{\circ} \mathrm{C}$ relative to a $1961-1990 \mathrm{CE}$ reference period and $-0.1^{\circ} \mathrm{C}$ relative to the 30-year period around the event, as well as a relatively weak and spatially incoherent climatic response in comparison to the less explosive but longer-lasting Icelandic Eldgjá $939 \mathrm{CE}$ and Laki $1783 \mathrm{CE}$ eruptions. In addition, the Veiðivötn 1477 CE eruption occurred around the inception of the Little Ice Age and could be used as a chronostratigraphic marker to constrain the phasing and spatial variability of climate changes over this transition if it can be traced in more regional palaeoclimatic archives.

\section{Introduction}

\subsection{Assessing the timing, strength and climatic impact of volcanic eruptions}

Volcanic eruptions are a key source of natural climatic variability, with the sulfate aerosols they emit into the stratosphere shielding the Earth from solar radiation and causing short-term cooling from a local to global scale (Robock, 2000; Sigl et al., 2015). Reconstructing climatic variability caused by past volcanic forcing improves understanding of responses, feedbacks and internal variability in the climate system that can help increase the accuracy of future climate predictions (Schurer et al., 2013; Bethke et al., 2017). Two key proxies provide evidence for these reconstructions: tree rings, which record terrestrial climatic changes that could be related to volcanic eruptions, and polar ice cores, which record the atmospheric burden of sulfate aerosols produced by past volcanic eruptions. Both archives have independent annually resolved chronologies that can be used to determine the timing of past volcanic events and their climatic impact. However, the quantification of post-volcanic climate responses has been hampered by differences in simulated and reconstructed temperature changes as well as potential mismatches in timing between the archives, which raised questions about the robustness of both tree-ring and ice-core chronologies (e.g. Baillie, 2008; Anchukaitis et al., 2012; Esper et al., 2013; Büntgen et al., 2014). Age uncertainties can arise from cumulative age uncertainties in the annual layer interpretation of ice cores, the brevity of the growth phase of tree rings during the Northern Hemisphere summer, and the time lag between sulfur emissions at a volcanic source and subsequent deposition of sulfuric aerosols on polar ice sheets, which can range from a few weeks up to a year depending on location and other eruption source parameters (e.g. Marshall et al., 2019). While the majority of the potential chronological mismatches have been resolved using new ice-core chronologies and long-term hemispheric-wide treering-based climate reconstructions (Sigl et al., 2015; Stoffel et al., 2015; Wilson et al., 2016), several enigmas re- main. The most notable of these unsolved questions is the apparent discrepancy between the timing of two major sulfuremitting volcanic eruptions, including the largest sulfateloading event in the last 700 years, and large-scale climatic cooling observed during the 1450s CE (Esper et al., 2017). This time period also aligns with the inception of the "Little Ice Age" (LIA; Grove, 2012) in the Northern Hemisphere (e.g. Owens et al., 2017; Büntgen et al., 2020).

The large sulfate-loading eruption during the 1450s CE has most commonly been attributed to the formation of the submarine Kuwae caldera offshore of Vanuatu in the South Pacific. This attribution is based on radiocarbon dating of charcoal that places the event, first described in oral histories of local islands (see Ballard, 2020), in the mid-15th century (Monzier et al., 1994; Robin et al., 1994) and petrological evidence that it was a sulfur-rich eruption (Witter and Self, 2007). This attribution has become commonly accepted within the literature despite a lack of confirmatory evidence. In recent studies, however, this source has been challenged or not attributed to the event (e.g. Németh et al., 2007; Esper et al., 2017; Toohey and Sigl, 2017; Hartman et al., 2019).

\subsection{Timing of volcanic eruptions in the $1450 \mathrm{~s}$ CE}

Through the study of bristlecone pines in the western USA, LaMarche and Hirschboeck (1984) identified a series of frost rings, including a widespread frost ring in $1453 \mathrm{CE}$, that they attributed to large volcanic eruptions. Filion et al. (1986) and Delwaide et al. (1991) also reported light rings related to $1453 \mathrm{CE}$ in more than $25 \%$ of subfossil black spruce trees sampled in subarctic Quebec. Briffa et al. (1998) subsequently identified a distinct cooling event in $1453 \mathrm{CE}$, recorded at multiple sites within their circum-northern hemispheric network of tree-ring chronologies from the northern boreal forest, while Salzer and Hughes (2007) identified evidence for anomalous tree-ring growth in the early and late 1450 s CE in western USA bristlecone pines. More recently, warm-season temperature reconstructions from Northern Hemisphere tree-ring networks have revealed spatially coherent and exceptional cooling in $1453 \mathrm{CE}$, with cooling ranging spatially between -0.4 and $-6.9^{\circ} \mathrm{C}$, marking the onset of a 15-year cold period (Stoffel et al., 2015; Esper et al., 2017; Guillet et al., 2017).

Various glaciochemical studies on Antarctic ice cores have provided evidence for a large volcanic event around $1450 \mathrm{CE}$ (e.g. Zanolini et al., 1985; Legrand and Kirchner, 1990; Moore et al., 1991). Delmas et al. (1992) suggested that this so-called "1450 event" was derived from a Southern Hemisphere eruption based on a limited coeval signal in Greenland (Hammer et al., 1980) and associated it with the climate cooling in the tree-ring records to attribute it an age of $1452 \mathrm{CE}$. Langway et al. (1995) subsequently identified a bipolar volcanic event to which they attributed an age of $1459 \mathrm{CE}$, and Zielinski (1995) attributed this to the large mid-15th century volcanic event. Later, in their compilation of 33 ice cores 


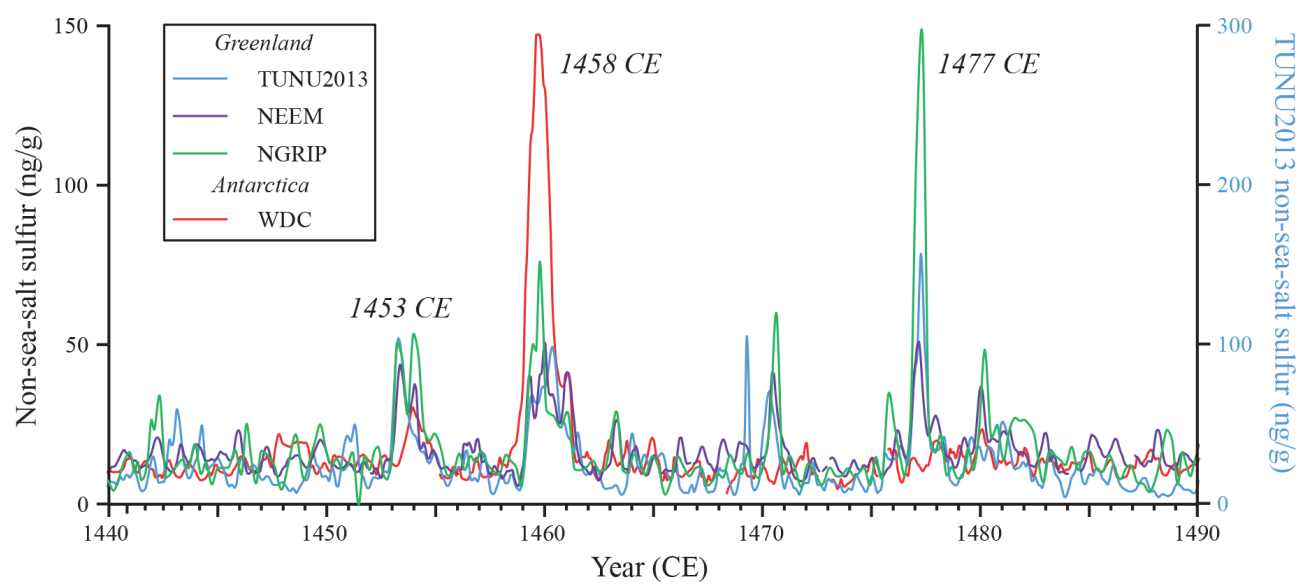

Figure 1. Bipolar comparison of sub-annual-resolution ice-core non-sea-salt sulfur concentrations between 1440 and $1490 \mathrm{CE}$. Greenland data from the NEEM-2011-S1 ice core (Sigl et al., 2013), the TUNU2013 ice core (Sigl et al., 2015) and the North Greenland Ice Core Project (NGRIP) ice core (Plummer et al., 2012), all plotted using the annually counted NS-2011 chronology (Sigl et al., 2015). Antarctic data are from the annually counted West Antarctic Ice Sheet Divide (WDC) ice core on the WD2014 age scale (Sigl et al., 2016).

from Greenland and Antarctica, Gao et al. (2006) suggested that the 1459 CE signal was from an eruption local to Greenland and concluded that the major Southern Hemisphere volcanic eruption occurred in late 1452 CE or early 1453 CE. However, this study overlooked that many of the ice-core chronologies from Antarctica were fixed to the tree-ring minima of 1453 CE following Briffa et al. (1998). Within the recent high-resolution ice-core-based independent volcanic reconstructions of Plummer et al. (2012) and Sigl et al. (2013, 2014, 2015) from both Greenland and Antarctica, two distinct sulfate peaks can be observed in the 1450s CE (Fig. 1). To provide a consistent terminology these unknown volcanic eruptions have been labelled after the year in which the increase in volcanic sulfate is first detectable in the records (i.e. $1453 \mathrm{CE}$ and $1458 \mathrm{CE}$ ). The actual eruption date is either in the same year or the previous year, due to the potential time delay of volcanic sulfate deposition on the ice-core sites (e.g. Marshall et al., 2019). The bipolar expression of these sulfate signals indicates that a comparatively smaller volcanic eruption, with a sulfate burden similar to that following Krakatau in $1883 \mathrm{CE}$, occurred in the low latitudes in 1452 or early $1453 \mathrm{CE}$ and was followed by a massive low-latitude event in 1458 CE (Fig. 1; Sigl et al., 2013). Sulfur isotope analysis of the two peaks in ice cores from Greenland and of the 1458 CE peak in Antarctica shows that both of these eruptions injected sulfur gases into the stratosphere and thus had the potential to impact global climate (Baroni et al., 2008; Cole-Dai et al., 2013; Gautier et al., 2019).

Sigl et al. (2013) argued that the first eruption in $1453 \mathrm{CE}$ caused the major climatic changes recorded in the tree-ring archives, that $1458 \mathrm{CE}$ is the correct age for the large sulfate peak in the mid-1450s CE recorded at both poles and that this event contributed to the decadal persistency of the cooling but triggered less distinct climatic changes that were only recorded in some tree-ring records (e.g. Salzer and Hughes, 2007). Subsequently, based on the new ages from two ice cores from Antarctica and observations from their tree-ring network, Esper et al. (2017) proposed two scenarios for the larger of the two volcanic events in the 1450s CE: either the original age of 1452 CE proposed by Delmas et al. (1992) for ice cores in Antarctica was correct and the cooling observed in the tree-ring records in $1453 \mathrm{CE}$ was caused by this event, or it occurred in $1458 \mathrm{CE}$ and did not cause large-scale cooling in the Northern Hemisphere extratropics. While omitting a discussion of the second major event in the 1450s CE, Esper et al. (2017) suggested that the first scenario is more likely and contended that the dendroclimatological evidence Sigl et al. (2013) used to support their dating to $1458 \mathrm{CE}$ provides insufficient support for the new age for the larger sulfate-loading eruption. Here we further explore this debate and the scenarios proposed by Sigl et al. (2013) and Esper et al. (2017) by testing the accuracy of the recent ice-core chronologies using a tephra horizon from a historically dated Icelandic eruption.

\subsection{Determining the source of volcanic eruptions in ice cores}

While comparisons of the relative peak sulfate concentrations between ice cores from Greenland and Antarctica can be used to assess if volcanic events occurred in the Southern or Northern Hemisphere extratropics or in the tropics (Sigl et al., 2015; see Sect. 5.1), sulfate records alone cannot pinpoint the exact source of an eruption. Particles of volcanic ash (glass tephra shards) may be preserved in ice cores following eruptions in association with sulfate peaks, and their chemical composition is a fingerprint of their volcanic source. Through geochemical analysis of individual glass shards and comparisons to characterisations of proximal deposits it is 
often possible to determine the volcanic source of these icecore tephra horizons (Abbott and Davies, 2012). The finegrained nature, low concentration of particles and lack of visible expression (i.e. cryptotephras) for many of these deposits make their identification and subsequent geochemical analysis challenging. However, a range of methods for the preparation and analysis of ice-core tephra samples has been developed and successfully applied to ice cores from Greenland and Antarctica (e.g. Dunbar et al., 2003; Davies et al., 2010a; Dunbar and Kurbatov, 2011; Coulter et al., 2012; Bourne et al., 2015, 2016; Iverson et al., 2017; Cook et al., 2018; Narcisi et al., 2019).

Identifying tephra in ice cores in direct association with sulfate peaks allows the volcanic source of those emissions to be determined with high certainty; however, it has been shown that tephra shards are not found in direct association with all sulfate peaks (e.g. Abbott et al., 2012; Coulter et al., 2012; Bourne et al., 2015). Despite this, any tephra-based source attributions are useful, especially for sulfate peaks assumed to link to known historical eruptions that provide keystone time markers for constructing, testing and synchronising ice-core chronologies (e.g. Öræfajökull 1362 CE - Palais et al., 1991; Laki 1783 CE - Fiacco et al., 1994; Katmai 1912 CE - Coulter et al., 2012). In addition, if such events occur in close association with other sulfate peaks of interest the dating control for all the events will be improved as the relative age differences between closely spaced peaks are more precise than absolute age estimates: so-called differential dating (Andersen et al., 2006). This approach has been used to resolve the timing, strength and climatic impacts of past volcanic events; for example, the identification of tephra in a Greenland ice core from the "Millennium Eruption" of Changbaishan (China and North Korea) (Sun et al., 2014) has helped to resolve these factors for that event and the earlier Icelandic Eldgjá eruption (Oppenheimer et al., 2017, 2018).

Here we explore whether tephra from the historically dated 1477 CE eruption of Veiðivötn-Bárðarbunga, Iceland, with which an obvious sulfate peak is commonly correlated and used as an age marker in Greenland ice-core chronologies (Fig. 1; Sigl et al., 2013, 2015), can be identified in a Greenland ice core. Direct attribution of this peak to the historical event will test and help improve ice-core dating around this marker and contribute to the debate regarding the strength and climatic impact of volcanic eruptions during the 1450s CE. In addition, attribution of the sulfate peak to the $1477 \mathrm{CE}$ Icelandic eruption would provide the opportunity to explore the climatic impact of sulfate emitted during this eruption. The $1477 \mathrm{CE}$ eruption was a notable event as it is considered to be one of the most explosive Icelandic eruptions during historical times, with a volcano explosivity index (VEI; Newhall and Self, 1982) of 6.

\section{Veiðivötn $1477 \mathrm{CE}$}

Iceland is the primary source of tephra horizons identified in the Greenland ice cores (e.g. Abbott and Davies, 2012; Bourne et al., 2015). As such, due to the high activity of many Icelandic volcanoes during the historical period (i.e. since the settlement of Iceland in the late 9th century CE), when many eruptions can be precisely dated to the year, month, day and even hour using documentary records, Icelandic tephra horizons can provide key markers to test icecore chronologies for the last $\sim 1100$ years (Larsen et al., 2014). The Veiðivötn-Bárðarbunga volcanic system was one of the most active during the historical period based on the frequency of eruptions, with notable eruptions recorded in $1797 \mathrm{CE}, 1717 \mathrm{CE}, 1500 \mathrm{CE}, 1477 \mathrm{CE}, \sim 1410 \mathrm{CE}$ and $\sim 1159$ CE (Larsen et al., 1998, 2014). Of these events the large-volume phreatoplinian eruption in $1477 \mathrm{CE}$ was the most explosive and widespread, erupting over $10 \mathrm{~km}^{3}$ of basaltic tephra from a $60-65 \mathrm{~km}$ long fissure along the Veiðivötn lake basin, and ash from the early stages of the eruption, which lasted for at least $12 \mathrm{~h}$, was distributed over about half of Iceland to the $\mathrm{E}, \mathrm{NE}$ and $\mathrm{N}$ of the fissure (Larsen, 2005; Larsen et al., 2014; Fig. 2b). The pattern of dispersal of highly fragmented lithic material from this highly explosive eruption suggests an eruption column during the main phase of $>18 \mathrm{~km}$ height (Larsen, 2005) and the release of sulfuric gases from the sulfur-rich basaltic magma into the stratosphere. Tephra from the 1477 CE eruption has been identified at many proximal and medial sites in Iceland as a visible horizon, including in soil sections, lake sediment cores and in offshore marine cores (Fig. 2b). Two distal cryptotephra occurrences have been identified thus far (Fig. 2a), one in An Loch Mór, western Ireland (MOR-T1; Chambers et al., 2004), and another in Lake Getvaltjärnen, Sweden (Davies et al., 2007). These correlations are underpinned by major element analysis of individual glass shards but are supported by stratigraphic and geochronological evidence due to geochemical similarities between the basaltic products of the Veiðivötn volcanic system (see Sect. 5.3).

Early descriptions of deposits from this eruption proximal to Veiðivötn did not ascribe a historical date to the event as it was thought to have not been mentioned in written sources; however, it was assigned an age of $1480 \mathrm{CE} \pm 11$ years based on soil accumulation rates between dated tephra layers (Larsen, 1984). Subsequently, on the basis of geochemical evidence and field mapping, a correlation was found between the Veiðivötn deposits and tephra layer "a", a widespread historically dated deposit previously thought to have originated from the Kverkfjöll volcanic system (Thórarinsson, 1958; Benjamínsson, 1981; Larsen et al., 2013). Thórarinsson (1958) associated tephra layer "a" with an observed tephra-fall in the Eyjafjörður area, northern Iceland (Fig. 1), which was subsequently reported in a votive letter written on 11 March 1477 CE. Based on this a historical date of early $1477 \mathrm{CE}$, most likely February, can be ascribed to 


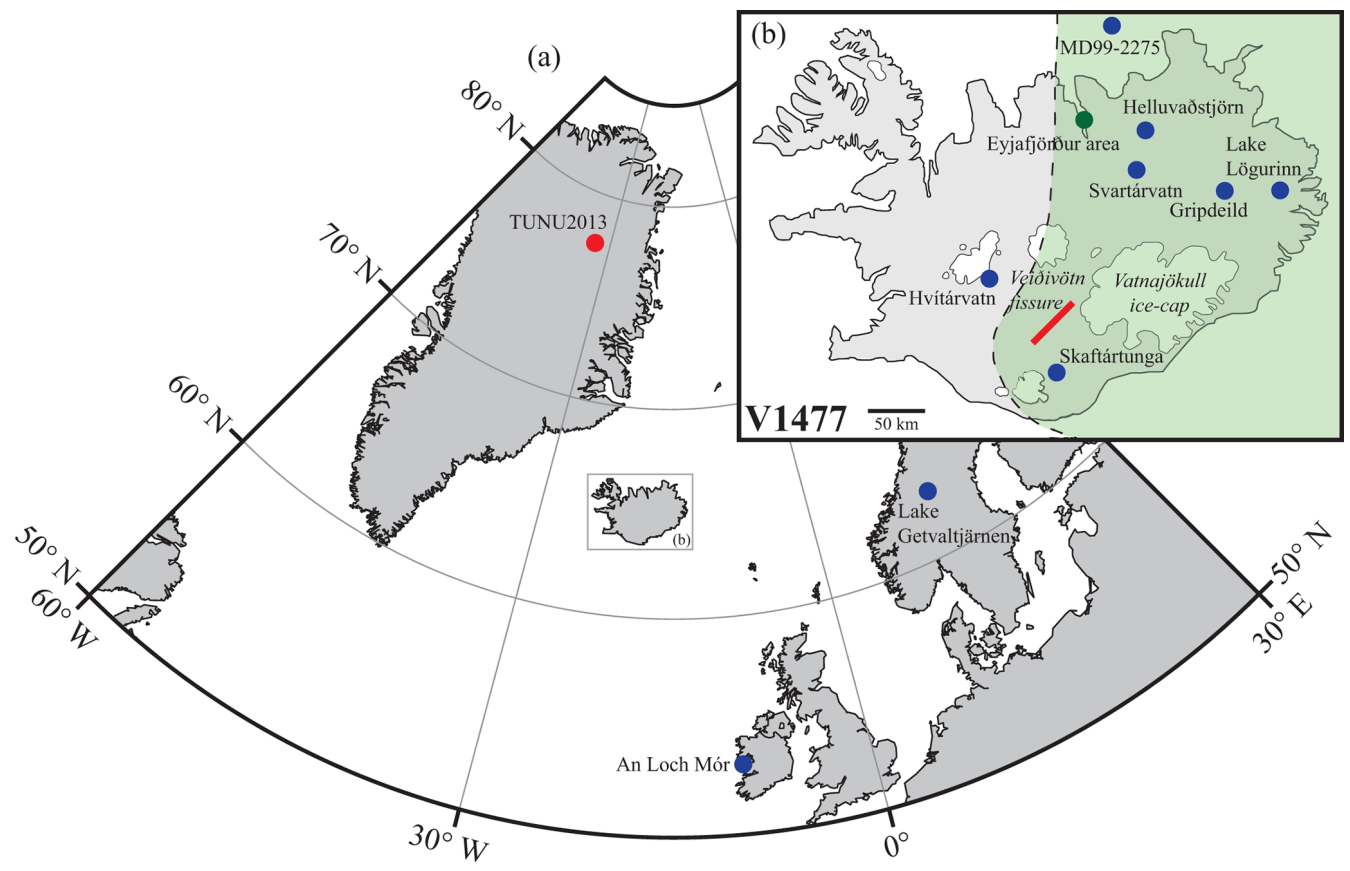

Figure 2. (a) Location map of the TUNU2013 ice-core drilling site and sites outside Iceland containing tephra attributed to the Veiðivötn 1477 CE eruption. (b) Location map of Icelandic sites containing tephra from the Veiðivötn $1477 \mathrm{CE}$ eruption, from which geochemical characterisations were used in this study, the location of the historical report of the eruption and the 60-65 km long fissure active during the 1477 CE eruption. The green shaded area covers the $0.5 \mathrm{~cm}$ isopach of the Veiðivötn $1477 \mathrm{CE}$ eruption. Adapted from Larsen et al. (2014).

the Veiðivötn-Bárðarbunga eruption, and it is henceforth referred to as V1477 (Guðrún Larsen, personal communication, 2020).

\section{Materials and methods}

\subsection{TUNU2013 ice-core chemistry and chronology}

The $213 \mathrm{~m}$ long TUNU2013 ice core was retrieved from northeastern Greenland during summer $2013\left(78.04^{\circ} \mathrm{N}\right.$, $33.88^{\circ} \mathrm{W}$; Fig. 2a) and covers the period between $280 \mathrm{CE}$ and 2013 CE. Ice-core sections were measured at the Desert Research Institute (DRI) using a continuous melter analysis system that includes two Element2 (Thermo Scientific) high-resolution inductively coupled plasma mass spectrometers operating in parallel to provide directly co-registered measurements of a broad range of $\sim 35$ elements, including sulfur, calcium and sodium (McConnell et al., 2002; Sigl et al., 2015; Maselli et al., 2017). There are several sources of sulfur in ice-core records; therefore, the sea salt component was removed to isolate the non-sea-salt (nssS) concentrations (Sigl et al., 2013). In addition to the elemental measurements, co-registered measurements of insoluble particle concentrations, in the size ranges of 2.6-4.5 and 4.5-9.5 $\mu \mathrm{m}$ diameter, were made using an inline Abakus ${ }^{\circledR}$ laser-based particle detector (Ruth et al., 2003). The nssS and fine particle concentrations were used to guide the tephra sampling towards depths with coeval peaks in both parameters. While the parti- cle measurements are not a direct proxy or solely controlled by the presence of tephra shards, this approach has successfully been used to identify tephra horizons in both Greenland and Antarctic ice cores (e.g. Jensen et al., 2014; Dunbar et al., 2017; McConnell et al., 2017, 2020; Plunkett et al., 2020; Smith et al., 2020).

The data from TUNU2013 were synchronised to the annually counted and seasonally resolved NS1-2011 chronology of Sigl et al. (2015) using a series of volcanic markers as tie points, including the sulfate peak thought to relate to V1477. The period covering 1450-1500 CE could be identified between $\sim 75.79$ and $82.20 \mathrm{~m}$, and clear peaks in sulfate thought to have started in 1453 CE, 1458 CE and 1477 CE were observed (Fig. 3a). During this time period the measurement resolution is $\sim 1 \mathrm{~cm}$ and annual layers are $\sim 12 \mathrm{~cm}$ thick; therefore, the data have a sub-annual, nominally monthly, resolution with a seasonal precision (i.e. $\sim 2$ months) due to variations in snowfall throughout the year. Annual layers were also counted in TUNU2013 between 1445 and $1485 \mathrm{CE}$ using concentration data for elements that show clear seasonal cycles, namely calcium and sodium, whose variations are driven by continental dust and oceanic sea spray deposition, respectively, and the nssS / Na ratio was used to define the annual layer boundary (Sigl et al., 2013; Maselli et al., 2017; Fig. 5). This annual layer count permits the full assessment of the ages of the two sulfate 

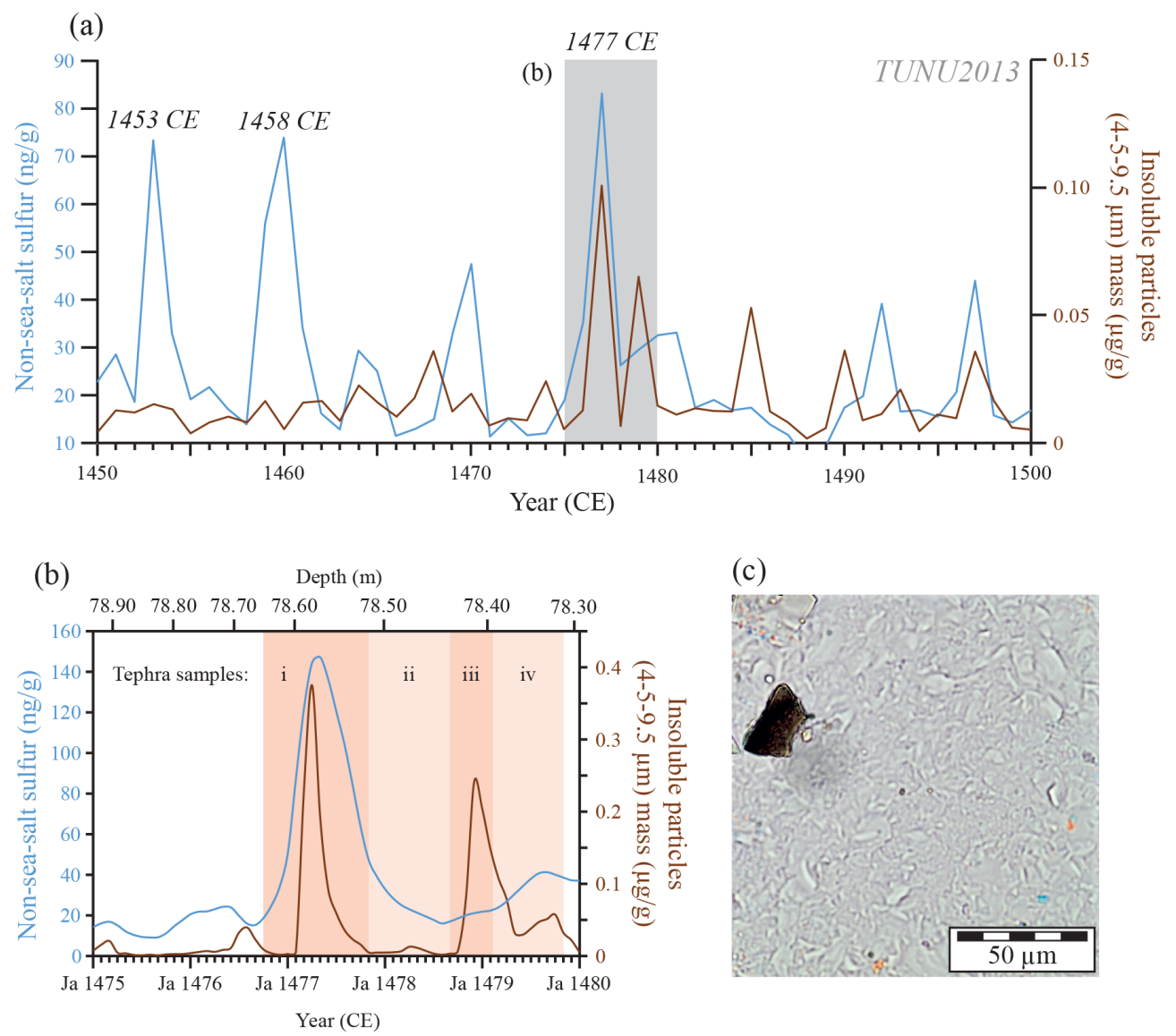

(c)

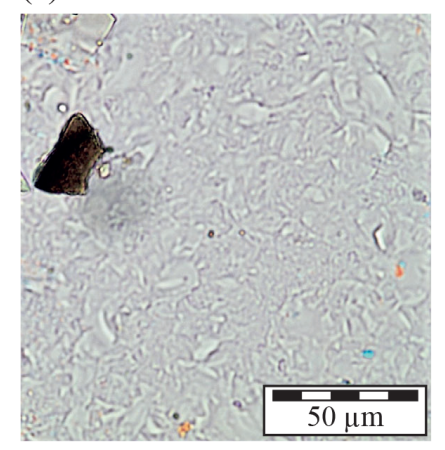

Figure 3. (a) Annual-resolution sulfur and particle concentration data from TUNU2013 between 1450 and 1500 CE. Data plotted using the NS1-2011 chronology. (b) Sub-annual-resolution sulfur and particle concentration data from TUNU2013 between 1475 and 1480 CE. Data plotted using the NS1-2011 chronology. Red bars denote depth intervals of tephra sampling. Tephra samples: (i) QUB-1965 $=78.515-$ $78.655 \mathrm{~m}$, (ii) QUB-1964 $=78.435-78.515 \mathrm{~m}$, (iii) QUB-1963 $=78.395-78.435 \mathrm{~m}$, (iv) QUB-1962 $=78.315-78.395 \mathrm{~m}$. (c) Example of a brown, platy glass tephra shard identified in the TUNU2013 $78.655 \mathrm{~m}$ deposit.

peaks in the 1450s CE in TUNU2013 using differential dating if the V1477 tephra is identified.

\subsection{Cryptotephra analysis}

The 1477 CE sulfate peak in TUNU2013 was accompanied by a coeval peak in particle concentration; thus, archived ice from the interval between 78.515 and $78.655 \mathrm{~m}$ was sampled directly for tephra analysis to determine if it related to the V1477 eruption (sample code QUB-1965; Fig. 3b). Direct ice samples (QUB-1964, QUB-1963 and QUB-1962) were also taken for tephra analysis across a later peak in particle concentrations, which according to the NS1-2011 chronology is centred around late $1478 \mathrm{CE}$ to early $1479 \mathrm{CE}$ and precedes a minor sulfate peak in middle to late 1479 CE (Fig. 3b).

The direct ice samples were transferred to individual Nalgene bottles and melted at room temperature; the meltwater was then centrifuged to concentrate any particulate material present. The concentrated meltwater was evaporated onto frosted $28 \times 48 \mathrm{~mm}$ microprobe slides and covered with
Buehler EpoxyCure 2 resin. The presence of glass tephra shards was assessed at $100-400 \times$ magnification using a polarising light microscope, and a significant concentration of shards was identified in QUB-1965. To section the glass shards and create a flat surface for geochemical analysis the epoxy mount was ground using $12 \mu \mathrm{m}$ alumina powder and then polished using 6,3 and $1 \mu \mathrm{m}$ diamond paste. The surface of the resin and exposed shards was then carboncoated prior to the concentrations of 11 major and minor elements within individual glass shards being analysed using a JEOL FEGSEM 6500F at Queen's University Belfast (QUB), which integrates wavelength and energy-dispersive spectrometry analysis (WDS and EDS, respectively; Coulter et al., 2010). Operating conditions followed Coulter et al. (2010) with the addition of $\mathrm{Cl}$ and $\mathrm{P}$ measured using EDS and WDS, respectively. Further details on the operating conditions are provided in Table S3 in the Supplement. Glass from the rhyolitic Lipari obsidian and the basaltic Laki 1783 CE tephra was analysed as secondary standards during the analytical period and compared to recommended values 
from Kuehn et al. (2011). A sample of V1477 tephra from Suðurárbotnar, northern Iceland (G. Guðrún Larsen, personal communication, 2020), was analysed as a QUB Veiðivötn internal standard. The raw sample and secondary standard analyses are provided in the Supplement (Tables S1 and S2).

Geochemical analyses from several occurrences of the V1477 tephra were collated for data analysis (Fig. 2; Table S4). To facilitate graphical and statistical comparisons between all datasets the geochemical data were normalised to an anhydrous basis (i.e. $100 \%$ total oxides) using eight elements consistently analysed in all studies. As such, the minor elements $\mathrm{MnO}, \mathrm{P}_{2} \mathrm{O}_{5}$ and $\mathrm{Cl}$ were not included, and their concentrations were deducted from the analytical totals prior to normalisation (see Table S4). Statistical comparisons were made between tephra occurrences using the statistical distance $\left(D^{2}\right)$ test described in Perkins et al. $(1995,1998)$ and the similarity coefficient (SC) function of Borchardt et al. (1972) (Tables S5 and S6).

\subsection{Tree-ring-based reconstructions of cooling induced by Icelandic eruptions}

\subsubsection{Impact of volcanic eruptions on Northern Hemisphere summer temperatures}

In addition to the ice-core and tephra analysis, we quantified the cooling induced by the V1477 eruption using the NVOLC v2 dataset of Guillet et al. (2020) and compared it to other major Icelandic eruptions of the Common Era. The NVOLC v2 dataset includes 13 tree-ring width (TRW) and 12 maximum latewood density (MXD) chronologies spread across the Northern Hemisphere (NH; for further details see Stoffel et al., 2015, and Guillet et al., 2017). All chronologies in NVOLC v2 have either been calibrated against regional instrumental climate data and transferred into temperature units or have been interpreted by the original authors as a temperature proxy. Here, a principal component regression (PCR) approach was chosen to transfer TRW and MXD data into NH summer (or JJA for June-July-August) temperature units, expressed as anomalies with respect to the 19611990 reference period. A reduced space signal of the proxy records was then extracted using principal component analysis (PCA), resulting in a set of principal component (PC) scores and PC loading patterns. The first $n$ PCs with eigenvalues $>1$ were retained as predictors to develop a multiple linear regression model. A multiple cross-validation using random calibration sets (bootstrapping) was applied to the PCR to estimate the skill of the reconstruction and confidence intervals around the reconstructed anomalies. Because each chronology had different lengths, an iterative nesting method was used to develop the temperature reconstruction. This procedure entails the subsetting of the original dataset into complete data matrices without missing values, so-called nests.
In NVOLC v2, 23 nests have been adjusted to the common period of all series. The earliest spans the period 500$551 \mathrm{CE}$ and is composed of six chronologies. The most replicated nest (1230-1972 CE) included 25 chronologies. The nested PCR was computed schematically following a threestep procedure. In each nest, the number of predictor variables was first reduced using a principal component analysis; secondly, the PCs with eigenvalues $>1$ were retained as independent variables within ordinary least-square (OLS) multiple regression models, while a mean NH JJA temperature series, obtained from the Berkeley Earth Surface Temperature (BEST) dataset over the period 1805-1972 CE, was used as a dependent variable. The robustness of each model was tested based on a traditional split calibration-verification procedure bootstrapped 1000 times, and the final reconstruction of each nest was computed as the median of the 1000 realisations given with their $95 \%$ confidence interval. The skill of each reconstruction has been evaluated based on the coefficient of determination $\left(r^{2}\right.$ for the calibration and $R^{2}$ for the verification periods), reduction of error (RE) and coefficient of efficiency (CoE) statistics. The final reconstruction (500-2000 CE) was achieved by splicing all the nested time series after the mean and variance of each nested reconstruction segment had been adjusted to the best replicated nest (1230-1972 CE). Finally, reconstructed temperature anomalies are presented as deviations from the 30-year mean climatology around the year of the volcanic eruption. For example, for V1477, a background was calculated by averaging the windows 1462-1476 CE and 1478-1493 CE, and then an anomaly was created by subtracting this background from the $1477 \mathrm{CE}$ reconstructed temperature.

\subsubsection{Regional variability of Northern Hemisphere summer cooling}

In order to characterise regional-scale climate changes and to reveal spatial anomaly patterns in the aftermath of Icelandic eruptions, we additionally used a network of tree-ring proxy data to develop a climate field reconstruction of extratropical NH JJA temperatures spanning the last 1500 years. In this approach, we grouped the 25 chronologies from NVOLC v2 into 11 regional clusters using a minimum coefficient correlation $(r)$ threshold above $0.3(p<0.05)$ over the common period of the chronologies. Based on the threshold, we included only one chronology in the Quebec, central Europe, Siberia-Taymir, Siberia-Yakutia and China-Qilian Mountains clusters, whereas five composed the western Europe region. In the six clusters that included multiple chronologies, we derived reconstructions from bootstrapped nested PCRs. In the remaining five clusters, we used a bootstrap OLS linear regression to quantify interannual variations of summer temperatures. Based on CoE statistics > 0.1, 3486 grid points have been reconstructed back to $500 \mathrm{CE}$. The smallest (Indigirka) and largest (Siberia-Polar Ural) clusters included 53 and 918 grid points, respectively. 


\section{Results}

\subsection{Cryptotephra analysis}

\subsubsection{CE sulfate peak}

A closer look at the sub-annual-resolution data around the sulfate peak attributed to $1477 \mathrm{CE}$ shows that particle concentrations peak in late winter $1477 \mathrm{CE}$ before sulfate concentrations peak approximately 2 months later during the spring, and elevated concentrations are broadly restricted to 1477 CE (Fig. 3b). Volcanic particles, including glass tephra shards, are transported and deposited rapidly (within days to weeks) following an eruption due to their relatively high density. However, the longer residence time of sulfate aerosols means that these concentrations can be elevated for an extended period following a volcanic eruption, which can be up to several years after a large eruption injecting aerosols high into the stratosphere (Robock, 2000). The relative time delay between peak particle and sulfate deposition can reflect the proximity of the eruptive source, with greater delays observed for more distal eruptions (e.g. Koffman et al., 2013, 2017; Smith et al., 2020). The sharp and narrow peak in sulfate concentrations observed in $1477 \mathrm{CE}$ (in contrast to the one starting in $1458 \mathrm{CE}$; Fig. 1) and the short delay following the particle concentration peak are more typical of a Northern Hemisphere eruption local to Greenland, and the timing of their deposition early in $1477 \mathrm{CE}$, i.e. during winter, is consistent with the historical date for the V1477 eruption.

Within the TUNU2013 ice sample covering a depth of 78.515-78.655 m (QUB-1965), 126 tephra glass shards were observed (Fig. 3c). These shards have a greenish-brown colour, display platy to blocky morphologies and no physical alternation, contain occasional microlites, and have longaxis diameters up to $30 \mu \mathrm{m}$. The major element composition of 16 of these shards was analysed, and they form a single homogenous population with a tholeiitic basaltic composition (Fig. 4ai). The most likely high-latitude Northern Hemisphere volcanic source of material of this composition is Iceland, and comparisons to the geochemistry of material proximal to several Icelandic volcanic systems show it was most likely sourced from the Veiðivötn-Bárðarbunga system (Fig. 4aii and iii).

Comparisons were made to the collation of geochemical analyses for proximal and distal occurrences of tephra produced during the V1477 event. Graphical comparisons show that for most element oxides, e.g. $\mathrm{Al}_{2} \mathrm{O}_{3}, \mathrm{TiO}_{2}, \mathrm{~K}_{2} \mathrm{O}$ and $\mathrm{SiO}_{2}$, there are close similarities between the concentrations observed in the TUNU2013 shards and the proximal and distal V1477 occurrences (Fig. 4bi and ii). However, for elements such as $\mathrm{Na}_{2} \mathrm{O}, \mathrm{FeO}$ and $\mathrm{MgO}$, some offsets, most notably of up to $1 \mathrm{wt} \%$ for $\mathrm{MgO}$, can be observed between the main populations (Fig. 4biii). However, some individual analyses from the V1477 occurrences, which could be dismissed as outliers, do have $\mathrm{MgO}$ concentrations similar to those from the TUNU2013 $78.655 \mathrm{~m}$ shards (Fig. 4biii).
The geochemical differences are reflected in statistical comparisons between the TUNU2013 tephra and the collation of V1477 data (Tables S5 and S6). Statistical distance tests show that in comparison to $\sim 36 \%$ of the V1477 occurrences the composition of TUNU2013 $78.655 \mathrm{~m}$ is statistically different at the $99 \%$ confidence interval, and the $D^{2}$ values for several other comparisons are just below the critical value (Table S5). A matrix of similarity coefficient comparisons between the average compositions of the tephra characterisations shows that all of the comparisons of prior V1477 occurrences have high values above the typical thresholds accepted as confirming that characterisations of Icelandic basaltic eruptions are identical, with all comparisons $>0.95$ and the vast majority $>0.97$ (Table S6). In contrast, comparisons between TUNU2013 $78.655 \mathrm{~m}$ and the V1477 occurrences range between 0.917 and 0.957 , values typically thought to indicate that the tephras originate from the same volcanic source but not the same eruption (Table S6; Begét et al., 1992; Abbott et al., 2018).

Geochemical offsets can result from tephra shards with the same composition being analysed under contrasting operating conditions on different microprobes and/or at different times (Kuehn et al., 2011). However, a comparison of secondary standard analyses from the analytical periods for the TUNU2013 shards and those from the Skaftártunga occurrence of V1477 (Streeter and Dugmore, 2014) strongly indicates that the geochemical offsets are not the result of analytical issues but are real differences in composition between the sample datasets (Fig. S1). Furthermore, the V1477 tephra analysed as a QUB Veiðivötn internal standard during the same analytical period as the TUNU2013 shards did not display the same $\mathrm{MgO}$ offset, but its $\mathrm{MgO}$ values are consistent with the main V1477 population (Fig. S2).

Overall, despite the geochemical offset, the evidence supporting the correlation of the TUNU2013 $78.655 \mathrm{~m}$ tephra layer with the V1477 event is strong. Firstly, the geochemical differences between TUNU2013 $78.655 \mathrm{~m}$ and the V1477 occurrences are only slight, and for most elements the concentrations are highly similar. Possible explanations for the differences in composition will be discussed in Sect. 5.4. Secondly, the ice-core chemistry and the shard geochemistry indicate that TUNU2013 $78.655 \mathrm{~m}$ was sourced from a Northern Hemisphere volcanic region close to Greenland and has a composition matching products of the VeiðivötnBárðarbunga volcanic system. Thirdly, while it is acknowledged that there can be uncertainties in ice-core chronologies, chronological uncertainties in this age range would be of the order of years rather than the tens to hundreds of years required for TUNU2013 $78.655 \mathrm{~m}$ to be the product of one of the other known Veiðivötn-Bárðarbunga eruptions (e.g. V1717, V1500, V1410), which have a similar geochemical composition. In addition, of these eruptions V1477 had the largest magnitude and thus the greatest potential for widespread deposition of its fallout. Lastly, as the Icelandic tephrostratigraphy is well documented over the last 
(a)
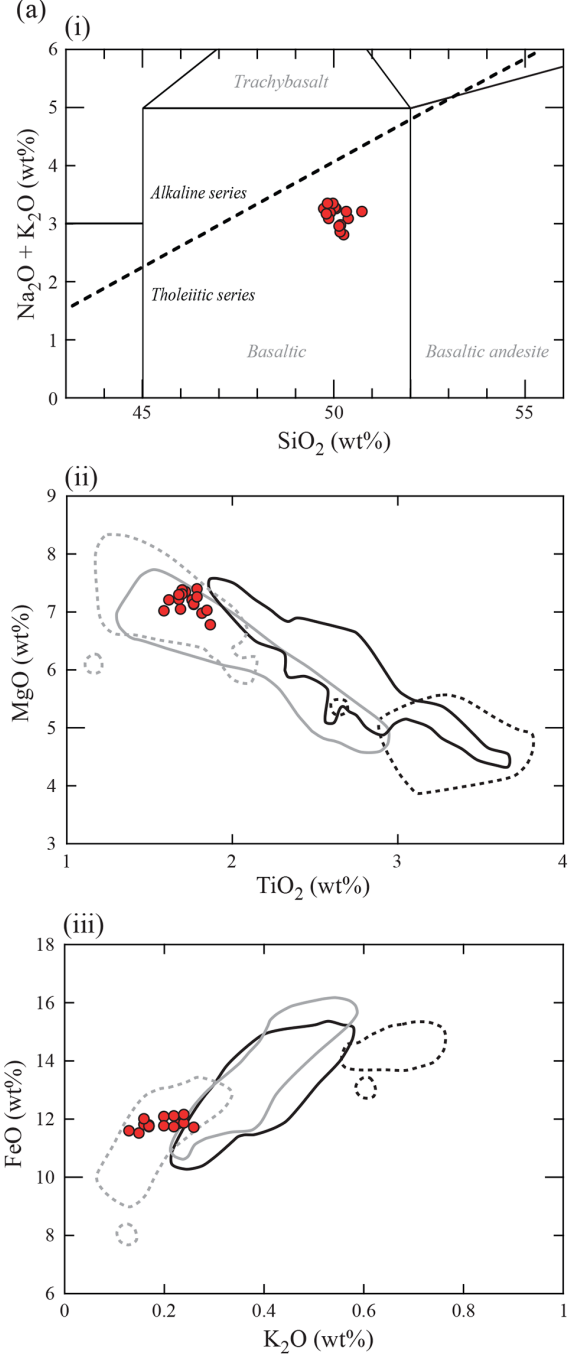

(b)
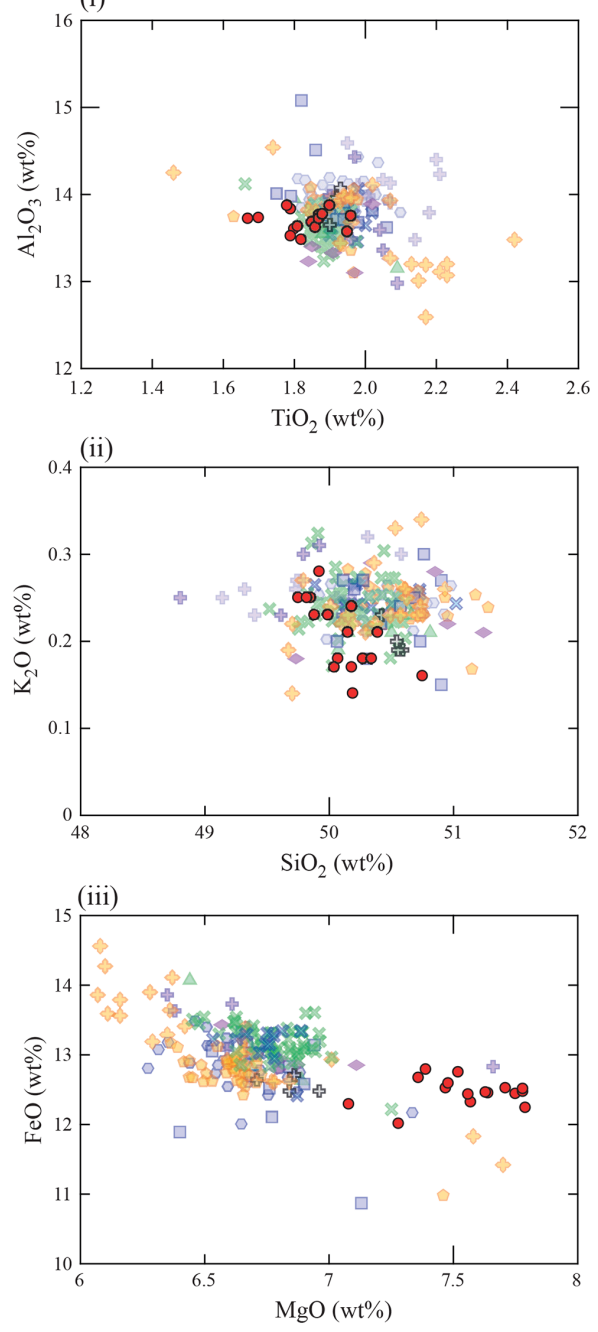

TUNU2013 78.655 m (QUB-1965)

Icelandic volcanic systems:

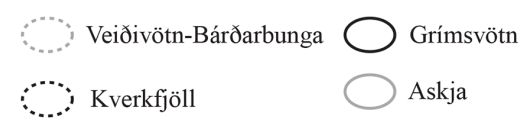

Veiðivötn 1477 CE occurrences:

$$
\begin{array}{ll}
\diamond \text { V1477, Svartárvatn } & \text { V1477, Gripdeild } \\
\text { ↔ V1477, Helluvaðstjörn } & \square \text { V1477, Vatnajökull comp. } \\
\text { \& V1477, Skaftártunga } & \text { MD99-2275 } 179 \mathrm{~cm} \\
\square \text { V1477, Hvítárvatn } & \triangle \text { MOR-T1, An Loch Mór } \\
\text { ※ V1477, Lake Lögurinn } & \square \text { Lake Getvaltjärnen 9-9.5 cm }
\end{array}
$$

Figure 4. Geochemical characterisation of glass tephra shards from the TUNU2013 $78.655 \mathrm{~m}$ deposit with comparisons to Icelandic proximal material and analyses of Veiðivötn 1477 CE occurrences. Panel (a) is as follows. (i) Inset of total alkali versus silica plot showing the tholeiitic basalt composition of the TUNU2013 $78.655 \mathrm{~m}$ deposit. Chemical classification and nomenclature after Le Maitre et al. (1989). Division line between alkaline and sub-alkaline material from MacDonald and Katsura (1964). (ii, iii) Geochemical characterisation of the TUNU2013 $78.655 \mathrm{~m}$ deposit compared to geochemical envelopes for several Icelandic tholeiitic volcanic systems. Geochemical envelopes derived from non-normalised whole rock and glass shard analyses from deposits proximal to the Icelandic volcanic systems; adapted from Óladóttir et al. (2020) and references within. Non-normalised TUNU2013 $78.655 \mathrm{~m}$ data utilised to permit a direct comparison with the published geochemical envelopes. Panel (b) is as follows. (i-iii) Comparisons of individual analyses from the geochemical characterisation of TUNU2013 $78.655 \mathrm{~m}$ to characterisations of several Icelandic and non-Icelandic occurrences of the Veiðivötn $1477 \mathrm{CE}$ eruption. Geochemical data for V1477 occurrences from Svartárvatn (Larsen et al., 2002), Helluvaðstjörn (Lawson et al., 2007), Skaftártunga (Streeter and Dugmore, 2014), Hvítárvatn (Larsen et al., 2011), Lake Lögurinn (Gudmundsdóttir et al., 2016), Gripdeild (Bergpórsdóttir, 2014), a compilation of six sites around the Vatnajökull ice cap (Óladóttir et al., 2011), MD99-2275 (Larsen et al., 2002; Gudmundsdóttir et al., 2011), An Loch Mór (Chambers et al., 2004) and Lake Getvaltjärnen (Davies et al., 2007). All data are provided in the Supplement and plotted on a normalised anhydrous basis. 
1000 years (e.g. Thordarson and Larsen, 2007; Larsen and Eiríksson, 2008), it is unlikely that TUNU2013 $78.655 \mathrm{~m}$ was deposited following a previously unknown eruption of the Veiðivötn-Bárðarbunga volcanic system of a sufficient magnitude to deposit tephra over Greenland.

\subsubsection{CE sulfate peak}

A limited number of tephra shards were found in the ice samples from the later microparticle peak at the start of $1479 \mathrm{CE}$, with up to three brown shards identified in both QUB-1963 and QUB-1962. A tephra layer with a rhyolitic composition was previously identified around $1479 \mathrm{CE}$ by Fiacco et al. (1993) in the GISP2 ice core and attributed to an eruption from Mount St. Helens, USA, dated using dendrochronology (Yamaguchi, 1983), although the geochemical match with this source is ambiguous (Abbott and Davies, 2012). The relationship between microparticle and sulfate concentrations for the 1479 CE event in TUNU2013 matches the observations of Fiacco et al. (1993), which also showed a peak in microparticles preceding a sulfate peak by about half a year (Fig. 3b). The tephra shards from QUB-1963 and QUB-1962 have not yet been geochemically analysed due to their small size $(<20 \mu \mathrm{m})$ and low concentration. Therefore, it was not possible to determine if they correlate with the rhyolitic 1479 CE tephra of Fiacco et al. (1993); however, a geochemical correlation is unlikely as the physical characteristics of the TUNU2013 shards are indicative of a mafic composition. Based on the physical characteristics it is possible that these shards represent remobilised material from V1477; however, without geochemical analysis we cannot determine if this is the case or if the tephra derived from another eruption.

\subsection{Differential dating of volcanic events in the 1450s CE}

Through the identification of the V1477 tephra layer in TUNU2013, in direct association with the large sulfate peak at $\sim 78.56 \mathrm{~m}$, it is demonstrated that the prior assumption that it represents aerosol deposition from the $1477 \mathrm{CE}$ eruption of Veiðivötn is correct. As such, the assertion that $1477 \mathrm{CE}$ can be used as the age for this ice-core depth with 0 years of uncertainty is appropriate. Using this age as a fix point for the annual layer counts for TUNU2013 between $1445 \mathrm{CE}$ and $1485 \mathrm{CE}$ it is shown that the ages of $1453 \mathrm{CE}$ and $1458 \mathrm{CE}$ for the start of the two sulfate peaks in the 1450s CE are in agreement with those derived from the NS1-2011 chronology (Fig. 5). These ages were based on annual layer counts from NEEM-2011-S1 using an age of 1477 CE for a notable sulfate peak in that sequence (Sigl et al., 2015). The close correspondence between the nssS records from TUNU2013 and NEEM-2011-S1 and the strong annual signals in TUNU2013 provide further evidence to support those ages for the events (Fig. S3).

\subsection{Tree-ring-based reconstruction of summer temperature cooling induced by Icelandic eruptions}

Within the NVOLC v2 reconstruction, each nest passed all verification tests, $R^{2}$ and $\mathrm{RE}$, for the calibration period, as well as $r^{2}$ and $\mathrm{CoE}$ for the verification period. For the 1420-1650 CE period (Fig. 6a), the unfiltered reconstruction indicates a cooling in the aftermath of V1477 of $-0.35^{\circ} \mathrm{C}$ relative to the $1961-1990 \mathrm{CE}$ reference period, the 356 th coldest $\mathrm{NH}$ summer since $500 \mathrm{CE}$ (i.e. rank 356). By comparison, stronger cooling is observed following the Icelandic Eldgjá $939 \mathrm{CE}\left(-0.5^{\circ} \mathrm{C}\right.$ in $940 \mathrm{CE}$, rank 205) and Laki $1783 \mathrm{CE}\left(-1.2^{\circ} \mathrm{C}\right.$, rank 9) eruptions. More extreme negative anomalies are observed following other major explosive volcanic eruptions, including $-1.6{ }^{\circ} \mathrm{C}$ in $1601 \mathrm{CE}$ (rank 1 , Huaynaputina), $-1.5^{\circ} \mathrm{C}$ in $1816 \mathrm{CE}$ (rank 3 , Tambora), $-1.4{ }^{\circ} \mathrm{C}$ in $536 \mathrm{CE}$ (rank 4 , unidentified volcano) and $-1.3^{\circ} \mathrm{C}$ in $1453 \mathrm{CE}$ (rank 5, unidentified volcano) (Fig. 6a). After filtering with a 30-year running mean centred around the year of the calculated anomaly, the NH summer cooling prevailing in $1477 \mathrm{CE}$ was $-0.1^{\circ} \mathrm{C}$ (Fig. 6b), the 524 th coldest $\mathrm{NH}$ summer since $500 \mathrm{CE}$. Our findings are corroborated through comparisons with other recent largescale reconstructions, Sch2015 (Schneider et al., 2015) and NTREND2015 (Wilson et al., 2016), which rank $1477 \mathrm{CE}$ as the 538th $\left(-0.04^{\circ} \mathrm{C}\right)$ and 182 th $\left(-0.23^{\circ} \mathrm{C}\right)$ coolest summers, respectively (Fig. 6b). The Sch2015, NTREND2015 and NVOLC v2 reconstructions all show more significant cooling in the aftermath of the Eldgjá and Laki eruptions, with cooling ranging between -0.4 and $-0.6^{\circ} \mathrm{C}$ and between -0.7 and $-1{ }^{\circ} \mathrm{C}$, respectively (Fig. 6b). Grouping the 25 chronologies into 11 clusters enables an estimation of the regional variability of summer cooling induced by the Icelandic eruptions (Fig. 6c). Based on this approach, the JJA gridded temperature reconstructions for $940 \mathrm{CE}$ and $1783 \mathrm{CE}$ (Fig. 6c) indicate that volcanic forcing induced widespread cooling over the NH. Extremely cold conditions prevailed in Scandinavia, western Europe and coastal Alaska in $940 \mathrm{CE}$, as well as on the Yamal Peninsula and in Alaska in $1783 \mathrm{CE}$. Less consistent patterns are observed in the reconstructed temperatures following the V1477 eruption, with cold temperatures in Scandinavia, western Europe and central Asia, contrasting with above-average anomalies over North America, in the Polar Ural and on the Yamal Peninsula (Fig. 6c).

\section{Discussion}

\subsection{Confirming the timing and hemisphere of mid-15th century volcanic eruptions}

The identification of the V1477 tephra layer in TUNU2013 has demonstrated the veracity of the age of $1477 \mathrm{CE}$ commonly used for a keystone sulfate peak identified in many ice cores from Greenland. This provides evidence to support the accuracy of the NS1-2011 Greenland ice-core chronol- 


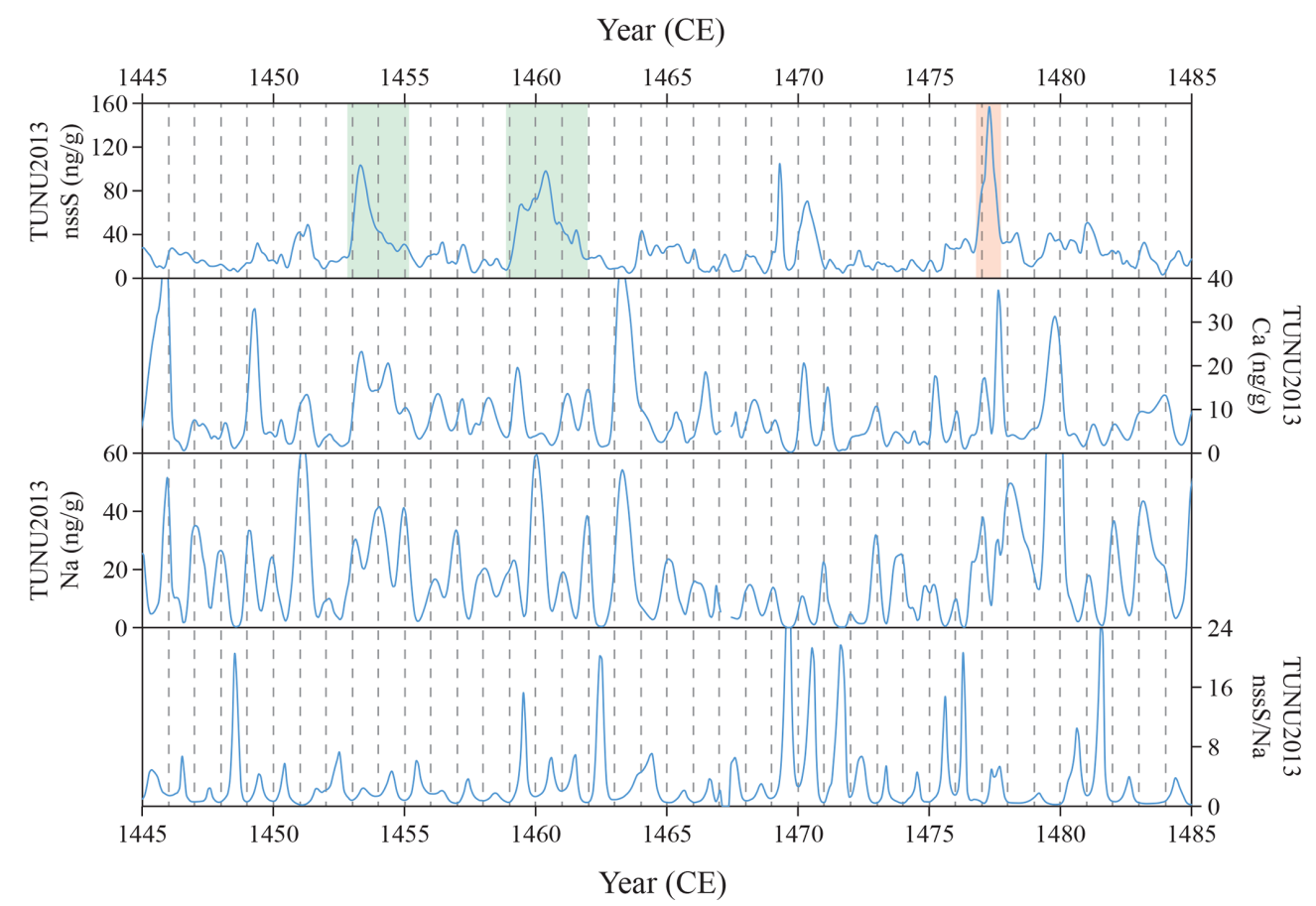

Figure 5. High-resolution nssS and annual layer dating of the TUNU2013 ice core between 1445 and 1485 CE using a multiparameter approach. Concentration records are shown for nssS, Ca, Na and nssS / Na, with grey dashed lines indicating the assigned years. The red shaded bar indicates the location of the V1477 tephra layer in the TUNU2013 record. The green shaded bars indicate the two sulfate peaks in the 1450s CE in TUNU2013.

ogy around this period and corroborates the ages proposed by Sigl et al. (2013) for the sulfate peaks in the mid-1450s CE in the Greenland ice-core records deposited following large volcanic eruptions in 1452 or early $1453 \mathrm{CE}$ and $1458 \mathrm{CE}$. The ages, temporal separation and duration of sulfate deposition for these events are consistent with those for two volcanic eruptions recorded in the Antarctic WDC core, whose ages were derived using an independent annually counted timescale and not bipolar synchronisation of the sulfate records (Sigl et al., 2013; Fig. 1). As highlighted by Sigl et al. (2013), the sulfate deposition in Greenland relating to the later event is greater than for the earlier event and is also consistent with the record from Antarctica. Further independent confirmation of the matching of the events could be achieved if the temporal evolution of sulfur isotope anomalies over the peak starting in $1458 \mathrm{CE}$ were consistent between ice cores from both polar ice sheets, as was demonstrated recently for the Samalas 1257 CE eruption (Burke et al., 2019).

While factors other than latitude may influence the stratospheric distribution of sulfate between the two hemispheres, aerosol modelling suggests that a likely range of latitudinal positions for eruption sources can be approximated based on the asymmetry of sulfate deposition between Greenland and Antarctica (Toohey et al., 2016, 2019; Marshall et al., 2019). Cumulative sulfate deposition for the $1453 \mathrm{CE}$ event was higher in Greenland $\left(25 \mathrm{~kg} \mathrm{~km}^{-2}\right)$ than in Antarctica $\left(5 \mathrm{~kg} \mathrm{~km}^{-2}\right)$, as deduced from a network of polar ice cores (Sigl et al., 2014; Toohey and Sigl, 2017). This suggests that $83 \%$ of the atmospheric sulfate burden remained in the Northern Hemisphere, which is more likely to occur after an eruption from a source located in that hemisphere. Conversely, for the $1458 \mathrm{CE}$ event, sulfate deposition was higher in Antarctica $\left(64 \mathrm{~kg} \mathrm{~km}^{-2}\right)$ than in Greenland $\left(35 \mathrm{~kg} \mathrm{~km}^{-2}\right)$, suggesting that $64 \%$ of the atmospheric sulfate burden remained in the Southern Hemisphere and that we can attribute the eruption to a source in that hemisphere.

As such, these findings demonstrate that the scenario proposed, but not favoured, by Esper et al. (2017), is correct; i.e. a strongly asymmetric Southern Hemisphere sulfate-loading event occurred in 1457 or $1458 \mathrm{CE}$ without causing largescale Northern Hemisphere cooling. In addition, the findings back up the argument of Sigl et al. (2013) that the first eruption in 1452 or early 1453 CE occurred in the Northern Hemisphere and caused the distinct climatic cooling observed in the tree-ring records. The close succession of the two large sulfur-rich volcanic eruptions was most likely the cause of the longevity of the 15 -year cold period following $1453 \mathrm{CE}$.

\subsection{Testing ice-core chronologies and determining volcanic sources using tephra horizons}

This study has shown the power of using historically dated tephra horizons to test the accuracy of ice-core chronologies 
(a)

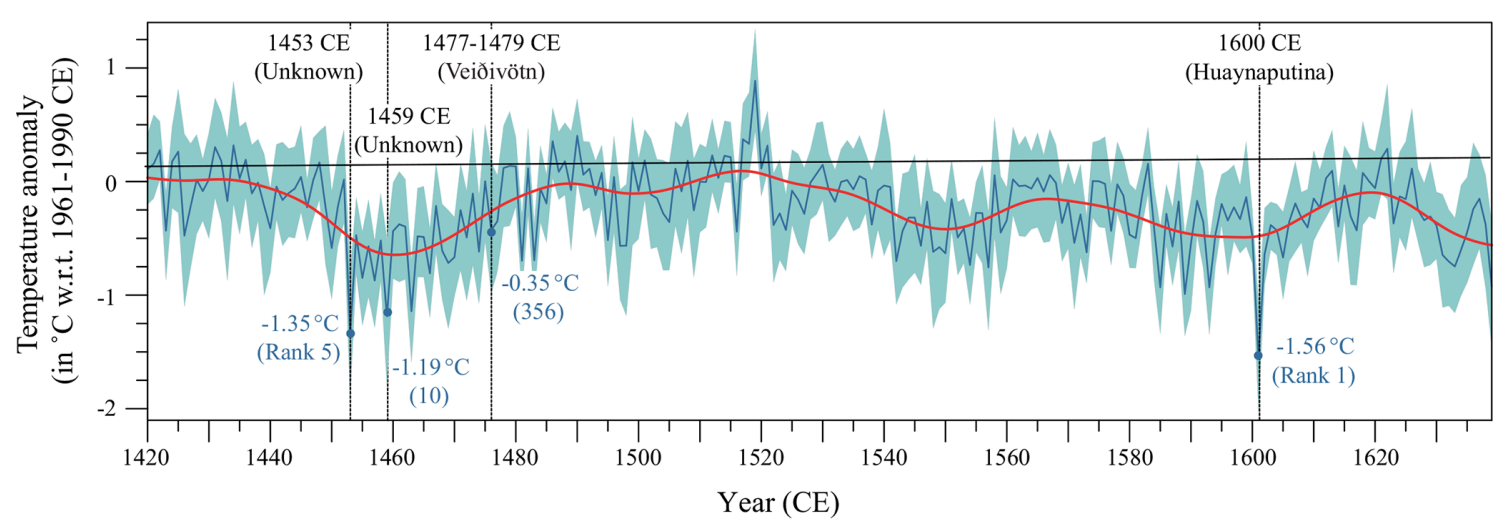

(b)
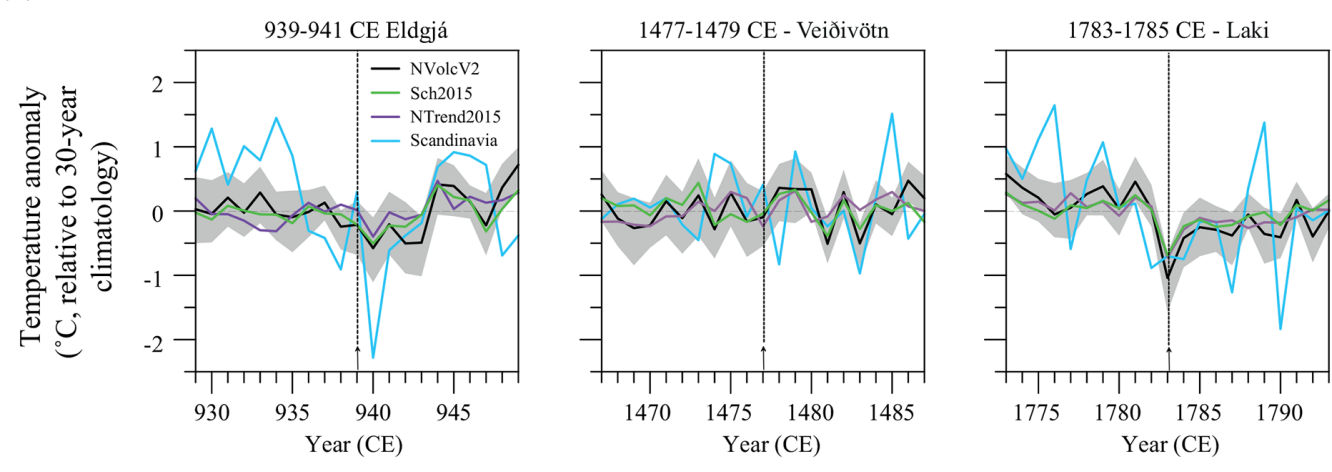

(c)
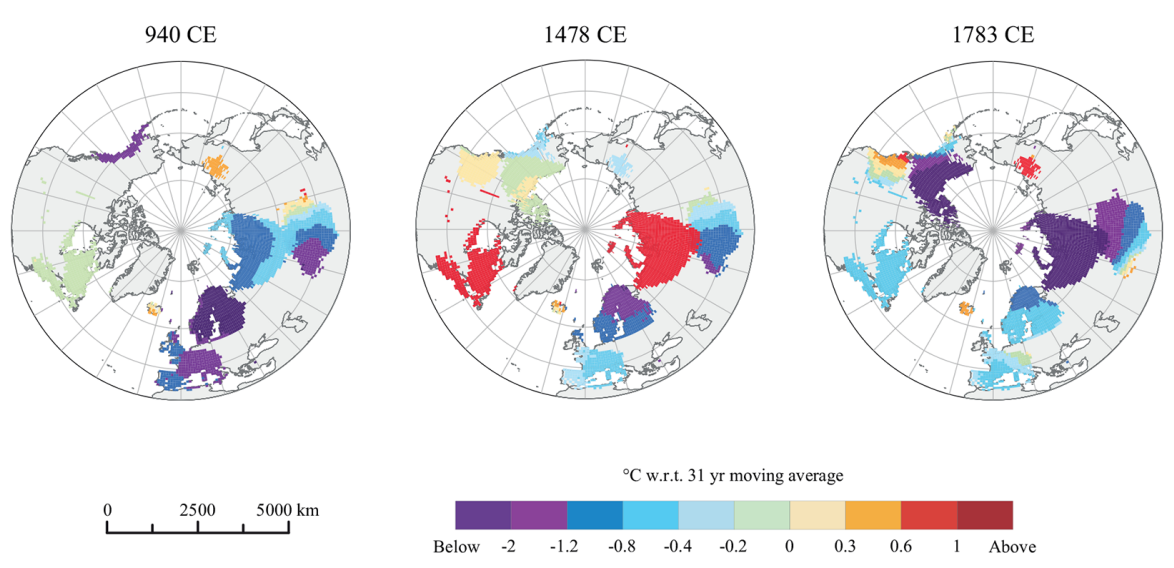

Figure 6. (a) Northern hemispheric $\left(40-90^{\circ} \mathrm{N}\right)$ summer (JJA) temperature reconstruction depicting the cooling induced by selected 15 th to 17 th century volcanic eruptions. The red line depicts 30 -year smoothed temperatures, whereas the blue line indicates annual temperature anomalies. The blue shaded area gives the $95 \%$ confidence interval. (b) Cooling induced by the most prominent Icelandic eruptions of the last 1500 years in 939 CE (Eldgjá), 1477 CE (Veiðivötn) and 1783 CE (Laki) in the NVOLC v2 (Guillet et al., 2020), Sch2015 (Schneider et al., 2015), NTREND2015 (Wilson et al., 2016) and Scandinavian cluster of NVOLC v2. (c) Spatial patterns of Northern Hemisphere temperatures the year following the three major Icelandic eruptions in the last 1500 years.

and assumptions regarding the source of sulfate aerosols deposited over ice sheets, which has critical implications for assessing the climatic impact of eruptions. The example provided here can be added to others from Greenland, with tephra from Öræfajökull 1362 CE, Laki 1783 CE and Katmai 1912 CE having all been identified in ice cores from Green- land in association with chemical indicators previously attributed to those eruptions (Palais et al., 1991; Fiacco et al., 1994; Coulter et al., 2012). Determining the source of notable peaks in sulfate or other volcanic indicators (e.g. acidity and electrical conductivity) using tephra is necessary, when possible, as associations with specific events can become em- 
bedded in the literature with limited supporting evidence, even if only originally proposed as a possibility. For example, associations between chemical indicators and the Hekla $1104 \mathrm{CE}$ and Vesuvius $79 \mathrm{CE}$ eruptions, which were previously used as historical tie points with no uncertainty while building chronologies (Hammer et al., 1980; Zielinski et al., 1994; Vinther et al., 2006), have been found to be inaccurate following re-evaluation of the Greenland ice-core chronologies (Sigl et al., 2015). The volcanic signal previously associated with the Hekla $1104 \mathrm{CE}$ eruption has been re-dated to $1108 \mathrm{CE}$, and Guillet et al. (2020) have recently proposed that it can be linked to an eruption of Mount Asama, Japan; however, at present this is not supported by tephra evidence. The volcanic signal previously associated with Vesuvius in $79 \mathrm{CE}$ has been re-dated to $87-88 \mathrm{CE}$ by Sigl et al. (2015). The re-evaluation of the Greenland ice-core chronology was aided by documented historical reports (Sigl et al., 2015) and cosmogenic radionuclides in tree rings and ice cores as another form of isochronous marker horizon, most likely produced by solar particle events (Miyake et al., 2012, 2015; Mekhaldi et al., 2015; Büntgen et al., 2018). This highlights the fact that tephra is just one of the tools that can be used to evaluate and improve ice-core chronologies.

Testing associations between volcanic indicators in ice cores and specific events using tephra could be useful for determining the source of the two eruptions in the 1450s CE, whose sources are currently unknown. The $1458 \mathrm{CE}$ event has often been attributed to the formation of the submarine Kuwae caldera; however, the evidence is inconclusive and circumstantial, so the source is still open for debate. Hartman et al. (2019) characterised tephra from an Antarctic ice core found in association with the $1458 \mathrm{CE}$ event and concluded that it was distinct to eruptive products from Kuwae; however, despite some geochemical similarities to the products of a local Antarctic volcano, a definitive source was not proposed. Based on the size of the particles and the expression of the sulfate in different ice cores, Hartman et al. (2019) suggest that it resulted from a tropospheric aerosol cloud; however, this is inconsistent with sulfur isotope evidence from Antarctica for stratospheric injection of the sulfate cloud (Baroni et al., 2008; Gautier et al., 2019). A local tropospheric source is also inconsistent with the widespread deposition of volcanic sulfate that prevailed for $2-3$ years as observed in a large network of 16 ice cores all over Antarctica (Sigl et al., 2014; Toohey and Sigl, 2017). Further studies of sulfur isotopes coupled with attempts to identify tephra associated with both events in the 1450s CE, as well as more work on proximal records, could aid in conclusively identifying their sources.

\subsection{Use of V1477 as a chronostratigraphic marker for the inception of the LIA}

The mid-15th century is widely considered to be the inception of the LIA (e.g. Owens et al., 2017; Büntgen et al.,
2020), which was potentially intensified by the large volcanic events in the 1450s CE (Miller et al., 2012; Schurer et al., 2014; Slawinska and Robock, 2018). As such, if the V1477 tephra layer could be traced in more palaeoclimatic archives it could act as a useful chronostratigraphic marker for constraining the chronology of different proxy records and assessing the phasing and spatial variability of climatic changes associated with the LIA onset. The identification of the V1477 tephra layer in a Greenland ice core corroborates the findings of past studies of terrestrial sequences from Ireland and Sweden (Chambers et al., 2004; Davies et al., 2007) that following the eruption its products were dispersed over a wide geographical area. Therefore, it has significant potential to act as a chronostratigraphic tie line linking records from Greenland, the North Atlantic and northwestern Europe. As one of the most explosive Icelandic eruptions of the last 1200 years, it is notable that V1477 has not already been identified at more sites and established as a key horizon in the tephrochronological framework for northern Europe (Lawson et al., 2012). The generally lower explosivity of Icelandic basaltic eruptions reduces the likelihood of the injection of material high into the atmosphere (Lawson et al., 2012), and the potential transport distance of the tephra is then dependent upon tropospheric conditions at the time of the eruption. Differences between glass shards produced during basaltic and rhyolitic eruptions may further constrain the long-range transport of basaltic glass tephra shards, with the greater density and generally larger grain size making the shards more prone to rapid fallout (Watson et al., 2017). However, it seems unlikely that these factors can explain the lack of more widespread V1477 occurrences in NW Europe given the prior distal identifications as well as the known high explosivity and plume height of the eruption. It has been proposed that basaltic tephra shards are not identified in some terrestrial sequences as they can degrade in acidic peatland environments (Pollard et al., 2003) or are overlooked in lake sediments due to the difficulties in separating and identifying basaltic shards (Lawson et al., 2012). In addition, nonidentification could be due to (1) spatial heterogeneity in distal ash deposition (Davies et al., 2010b), (2) latitudinal differences in wind strength, since although rarely identified in continental European sequences basaltic shards have been identified in a Russian Arctic site located a similar distance from Iceland but further north (Vakhrameeva et al., 2020), and/or (3) this specific time interval not being investigated. Therefore, we propose that the potential use of V1477 as a chronostratigraphic marker could be increased through focused cryptotephra investigations of specific time windows and, for lake sediments, incorporating magnetic separation processing (e.g. Mackie et al., 2002) to maximise the isolation of basaltic material.

A key consideration for any future studies aiming to trace V1477 is the strong similarity between the geochemical compositions of V1477 and other notable Veiðivötn-sourced tephra layers such as V1717, V1410 and V877, the Land- 
nám tephra (Cage et al., 2011; Harning et al., 2018). To date, only the V1477 and Landnám tephras have been definitively identified in European records, although the potential presence of tephra shards from other Veiðivötn eruptions (e.g. V1159, V1717, V1766 and V1797) has been discussed (Plunkett and Pilcher, 2018; Vakhrameeva et al., 2020). Therefore, in palaeoarchives with a lower temporal resolution than ice cores, independent chronological evidence would be required to support any correlations with specific Veiðivötn eruptions, such as the radiocarbon age Davies et al. (2007) used to support the correlation of the Lake Getvaltjärnen deposit with V1477.

\subsection{Geochemical variability of V1477 deposits}

A notable observation from this work was a slight geochemical offset between tephra shards from TUNU2013 $78.655 \mathrm{~m}$ and the V1477 occurrences (Fig. 4b). However, as outlined in Sect. 4.1.1 it does not hinder the attribution of TUNU2013 $78.655 \mathrm{~m}$ to V1477. The offsets are most notable for the $\mathrm{MgO}$ concentrations, which, except for a few outlier analyses from other deposits, are $\sim 0.75-1 \mathrm{wt} \%$ higher in the TUNU2013 shards (Fig. 4biii). $\mathrm{MgO}$ concentrations around $7-8 \mathrm{wt} \%$ are not atypical for Veiðivötn products (Fig. 4aii) but are more characteristic of Veiðivötn eruptions that occurred earlier in the Holocene than V1477 (Óladóttir et al., 2011; Caracciolo et al., 2020).

The difference in $\mathrm{MgO}$ concentrations could indicate that the TUNU2013 shards have a more primitive, i.e. less evolved, geochemical composition than shards from the other V1477 occurrences. A general trend of increasing MgO values with decreasing $\mathrm{FeO}$ concentrations can be observed in the V1477 data (Fig. 4biii) and is most obvious in the characterisation of V1477 from Skaftártunga (Streeter and Dugmore, 2014). Within the Skaftártunga characterisation, alongside shards with strong similarities to the other V1477 analyses, more geochemically evolved shards with lower $\mathrm{MgO}$ concentrations and higher $\mathrm{FeO}$ values than most of the other V1477 analyses can be observed, as can two shard analyses with $\mathrm{MgO}$ and $\mathrm{FeO}$ values comparable to the TUNU2013 $78.655 \mathrm{~m}$ data (Fig. 4biii). This overall trend could be indicative of geochemical evolution during the eruption; however, such clear fractionation trends are not observed for other element pairs. The bilobate form of proximal V1477 deposits on isopach maps and differences in the size and morphology of tephra shards between the lobes indicate that differential dispersal occurred with plumes to the ENE and NNW of the fissure (Benjamínsson, 1981). It has been suggested that the two lobes resulted from either a shift in wind direction from the SW to SE during the eruption (Benjamínsson, 1981) or bifurcation of the volcanic plume due to a crosswind (Ernst et al., 1994). A change in wind direction during the course of the eruption could have caused products from different temporal phases to be transported along the two dispersal axes and account for the slight differences between geochemical characterisations from specific sites. Geochemical variability between coarser and finer grain-size fractions deposited at more proximal and more distal sites, respectively, could also be a factor; however, significant differences in grain size are unlikely for the more distal deposits, and when compared they still display the offset in $\mathrm{MgO}$.

As prior studies have not identified the geochemical differences highlighted in this study the offsets could have resulted from analytical uncertainty; however, this is unlikely based on the secondary and internal standard analyses made when the TUNU2013 shards were analysed (Figs. S1 and S2). Further investigation of V1477 occurrences at proximal sites and in other Greenland ice cores could determine if the geochemical offset is consistent for other deposits along the same dispersal axis or can be related to grain-size differences, and the potential for offsets should be considered within any attempts to trace this horizon.

\subsection{Climatic impact of V1477 relative to other Icelandic eruptions}

The definitive attribution of the $1477 \mathrm{CE}$ sulfate peak in Greenland to the Icelandic V1477 eruption also provided an opportunity to assess the climatic impact of this explosive eruption in comparison to the effects of other historical eruptions. Overall, despite having a VEI of 6, the NH cooling following V1477 was relatively weak and spatially incoherent in comparison to the less explosive Icelandic Laki and Eldgjá eruptions (VEI 4-5) and more explosive lower-latitude eruptions, e.g. Tambora and Huaynaputina (Fig. 6; Sect. 4.3). The greater impact of the more effusive Icelandic eruptions relative to the V1477 eruption can be attributed to the huge sulfate load emitted during the Laki and Eldgjá eruptions over prolonged periods of time ( $\sim 8$ months and $>2$ years, respectively) in comparison to the short-lived (days to weeks) duration of the V1477 eruption (Thordarson et al., 2001; Thordarson and Larsen, 2007). The short residence time of sulfate in the atmosphere following the V1477 eruption is highlighted by the sharp and narrow nature of the $1477 \mathrm{CE}$ sulfate peak in the Greenland ice cores (Fig. 1).

\section{Conclusions}

Using sulfate and particle concentration records as a guide, volcanic ash from the Icelandic eruption of Veiðivötn in $1477 \mathrm{CE}$ has been identified as a cryptotephra in the TUNU2013 Greenland ice core. This identification verifies the widely assumed source of a notable sulfate peak present in many Greenland ice cores, and it confirms the accuracy of the NS1-2011 chronology around this depth. In addition, using annual layer counting the ages of $1452 \mathrm{CE}$ and $1458 \mathrm{CE}$ attributed to two volcanic events in the 1450s CE are confirmed with high accuracy. While being considered one of the most explosive Icelandic eruptions of the last 1200 
years, a tree-ring-based reconstruction of summer temperatures demonstrates that V1477 caused weak and spatially incoherent summer cooling in comparison to other recent Icelandic eruptions that, while less explosive, emitted a higher sulfate load. The timing of the eruption around the inception of the LIA in the NH means V1477 could act as a chronostratigraphic marker for assessing climatic changes associated with this onset. However, potential geochemical variability between V1477 deposits and geochemical similarities with the products of other eruptions from Veiðivötn must be considered when correlations are being assessed.

Data availability. The data presented and utilised in this study are available in the Supplement.

Supplement. The supplement related to this article is available online at: https://doi.org/10.5194/cp-17-565-2021-supplement.

Author contributions. All authors contributed to obtaining and analysing the data utilised in the study. MSi and GP conceived the research. JRM, NJC and MSi contributed ice-core glaciochemical records. GP and JRP performed tephra geochemical analyses. MSt and $\mathrm{CC}$ produced the North Hemisphere tree-ring-based summer temperature reconstruction. PMA wrote the paper with MSt and CC contributing Sects. 3.3 and 4.3 as well as Fig. 6. All authors contributed to improving and editing the paper.

Competing interests. The authors declare that they have no conflict of interest.

Special issue statement. This article is part of the special issue "Interdisciplinary studies of volcanic impacts on climate and society". It is not associated with a conference.

Acknowledgements. Thanks to Carla Grimaldi for compiling some of the V1477 geochemical data. Thanks to Guðrún Larsen for a detailed description of the history of the dating of V1477 and Esther Ruth Guðmundsdóttir for providing geochemical data from the V1477 occurrence in Lake Lögurinn. Thanks to Richard Streeter and Chris Hayward for providing secondary standard data related to the V1477 occurrence from Skaftártunga. We thank Karen Fontijn and an anonymous reviewer for their comments that have helped to improve the paper. Thanks also to Matthew Toohey, the guest editor for this paper, for his helpful comments. This research benefitted from the participation of the authors in the Volcanic Impacts on Climate and Society (VICS) working group of the Past Global Changes (PAGES) project.

Financial support. Peter M. Abbott and Michael Sigl received funding from the European Research Council under the Euro- pean Union's Horizon 2020 research and innovation programme (grant agreement no. 820047). Michael Sigl received funding from the Geoscience Department and the NFR TOPPFORK project "VIKINGS" (grant no. 275191) at the University of Oslo. The collection and analysis of the TUNU2013 core were supported by a US National Science Foundation grant (no. 1204176) to Joseph R. McConnell, with additional support provided (grant no. 1925417) to Joseph R. McConnell and Nathan J. Chellman for the volcanic interpretation. Markus Stoffel and Christophe Corona received funding from the Swiss National Science Foundation through the SNSF Sinergia CALDERA project (grant agreement no. CRSII5_183571).

Review statement. This paper was edited by Matthew Toohey and reviewed by Karen Fontijn and one anonymous referee.

\section{References}

Abbott, P. M. and Davies, S. M.: Volcanism and the Greenland ice-cores: the tephra record, Earth-Sci. Rev., 115, 173-191, https://doi.org/10.1016/j.earscirev.2012.09.001, 2012.

Abbott, P. M., Davies, S. M., Steffensen, J. P., Pearce, N. J. G., Bigler, M., Johnsen, S. J., Seierstad, I. K., Svensson, A., and Wastegård, S.: A detailed framework of Marine Isotope Stage 4 and 5 volcanic events in two Greenland ice-cores, Quaternary Sci. Rev., 36, 59-77, https://doi.org/10.1016/j.quascirev.2011.05.001, 2012.

Abbott, P. M., Griggs, A. J., Bourne, A. J., Chapman, M. R., and Davies, S. M.: Tracing marine cryptotephras in the North Atlantic during the last glacial period: Improving the North Atlantic marine tephrostratigraphic framework, Quaternary Sci. Rev., 189, 169-186, https://doi.org/10.1016/j.quascirev.2018.03.023, 2018.

Anchukaitis, K. J., Breitenmoser, P., Briffa, K. R., Buchwal, A., Büntgen, U., Cook, E. R., D’Arrigo, R. D., Esper, J., Evans, M. N., Frank, D., Grudd, H., Gunnarson, B. E., Hughes, M. K., Kirdyanov, A. V., Körner, C., Krusic, P. J., Luckman, B., Melvin, T. M., Salzer, M. W., Shashkin, A. V., Timmreck, C., Vaganov, E. A., and Wilson, R. J. S.: Tree rings and volcanic cooling, Nat. Geosci., 5, 836-837, https://doi.org/10.1038/ngeo1645, 2012.

Andersen, K. K., Svensson, A., Johnsen, S. J., Rasmussen, S. O., Bigler, M., Röthlisberger, R., Ruth, U., Siggaard-Andersen, M.-L., Steffensen, J. P., Dahl-Jensen, D., Vinther, B. M., and Clausen, H. B.: The Greenland Ice Core Chronology 2005, 1542 ka, Part 1: constructing the time scale, Quaternary Sci. Rev., 25, 3246-3257, https://doi.org/10.1016/j.quascirev.2006.08.002, 2006.

Baillie, M. G. L.: Proposed re-dating of the European ice core chronology by seven years prior to the 7th century AD, Geophys. Res. Lett., 35, L15813, https://doi.org/10.1029/2008GL034755, 2008.

Ballard, C.: The Lizard in the Volcano: Narratives of the Kuwae Eruption, Contemp. Pac., 32, 98-123, https://doi.org/10.1353/cp.2020.0005, 2020.

Baroni, M., Savarino, J., Cole-Dai, J. H., Rai, V. K., and Thiemens, M. H.: Anomalous sulfur isotope compositions of volcanic sulfate over the last millennium in Antarctic ice cores, J. Geophys. 
Res., 113, D20112, https://doi.org/10.1029/2008JD010185, 2008.

Begét, J., Mason, O., and Anderson, P.: Age, Extent and Climatic Significance of the c. 3400 BP Aniakchak Tephra, Western Alaska, USA, Holocene, 2, 51-56, https://doi.org/10.1177/095968369200200106, 1992.

Benjamínsson, J.: Tephra layer "a”, in: Tephra Studies, edited by: Self, S. and Sparks, R. S. J., Springer, Dordrecht, the Netherlands, 331-335, 1981.

Bergpórsdóttir, H. B.: A 3000 year high resolution multi-proxy record of environmental change from lake Gripdeild, eastern Iceland, University of Iceland, Reykjavík, Iceland, 85 pp., 2014.

Bethke, I., Outten, S., Otterå, O. H., Hawkins, E., Wagner, S., Sigl, M., and Thorne, P.: Potential volcanic impacts on future climate variability, Nat. Clim. Change, 7, 799-805, https://doi.org/10.1038/nclimate3394, 2017.

Borchardt, G. A., Aruscavage, P. J., and Millard, H. T.: Correlation of the Bishop Ash, a Pleistocene marker bed, using instrumental neutron activation analysis, J. Sediment. Res., 42, 301-306, https://doi.org/10.1306/74D72527-2B2111D7-8648000102C1865D, 1972.

Bourne, A. J., Cook, E., Abbott, P. M., Seierstad, I. K., Steffensen, J. P., Svensson, A., Fischer, H., Schüpbach, S., and Davies, S. M.: A tephra lattice for Greenland and a reconstruction of volcanic events spanning 25-45 ka b2k, Quaternary Sci. Rev., 118, 122141, https://doi.org/10.1016/j.quascirev.2014.07.017, 2015.

Bourne, A. J., Abbott, P. M., Albert, P. G., Cook, E., Pearce, N. J. G., Ponomareva, V., Svensson, A., and Davies, S. M.: Underestimated risks of recurrent long-range dispersal from northern Pacific Arc volcanoes, Sci. Rep., 6, 29837, https://doi.org/10.1038/srep29837, 2016.

Briffa, K. R., Jones, P. D., Schweingruber, F. H., and Osborn, T. J.: Influence of volcanic eruptions on Northern Hemisphere summer temperature over the past 600 years, Nature, 393, 450-455, https://doi.org/10.1038/30943, 1998.

Büntgen, U., Wacker, L., Nicolussi, K., Sigl, M., Güttler, D., Tegel, W., Krusic, P. J., and Esper, J.: Extraterrestrial confirmation of tree-ring dating, Nat. Clim. Change, 4, 404-405, https://doi.org/10.1038/nclimate2240, 2014.

Büntgen, U., Wacker, L., Diego Galván, J., Arnold, S., Arseneault, D., Baillie, M., Beer, J., Bernabei, M., Bleicher, N., Boswijk, G., Bräuning, A., Carrer, M., Charpentier Ljungqvist, F., Cherubini, P., Christl, M., Christie, D. A., Clark, P. W., Cook, E. R., D’Arrigo, R., Davi, N., Eggertsson, Ó., Esper, J., Fowler, A. M., Gedalof, Z., Gennaretti, F., Grießinger, J., Grissino-Mayer, H., Grudd, H., Gunnarson, B. E., Hantemirov, R., Herzig, F., Hessl, A., Heussner, K.-U., Jull, A. J. T., Kukarskih, V., Kirdyanov, A., Koláŕ, T., Krusic, P. J., Kyncl, T., Lara, A., LeQuesne, C., Linderholm, H. W., Loader, N. J., Luckman, B., Miyake, F., Myglan, V. S., Nicolussi, K., Oppenheimer, C., Palmer, J., Panyushkina, I., Pederson, N., Rybníček, M., Schweingruber, F. H., Seim, A., Sigl, M., Churakova (Sidorova), O., Speer, J. H., Synal, H.-A., Tegel, W., Treydte, K., Villalba, R., Wiles, G., Wilson, R., Winship, L. J., Wunder, J., Yang, B., and Young, G. H. F.: Tree rings reveal globally coherent signature of cosmogenic radiocarbon events in 774 and 993 CE, Nat. Commun., 9, 3605, https://doi.org/10.1038/s41467-018-06036-0, 2018.

Büntgen, U., Arseneault, D., Boucher, É., Churakova, O. V., Gennaretti, F., Crivellaro, A., Hughes, M. K., Kirdyanov, A. V.,
Klippel, L., Krusic, P. J., Linderholm, H. W., Ljungqvist, F. C., Ludescher, J., McCormick, M., Myglan, V. S., Nicolussi, K., Piermattei, A., Oppenheimer, C., Reinig, F., Sigl, M., Vaganov, E. A., and Esper, J.: Prominent role of volcanism in Common Era climate variability and human history, Dendrochronologia, 64, 125757, https://doi.org/10.1016/j.dendro.2020.125757, 2020.

Burke, A., Moore, K. A., Sigl, M., Nita, D. C., McConnell, J. R., and Adkins, J. F.: Stratospheric eruptions from tropical and extra-tropical volcanoes constrained using high-resolution sulfur isotopes in ice cores, Earth Planet. Sci. Lett., 521, 113-119, https://doi.org/10.1016/j.epsl.2019.06.006, 2019.

Cage, A. G., Davies, S. M., Wastegård, S., and Austin, W. E. N.: Identification of the Icelandic Landnám tephra (AD $871 \pm 2$ ) in Scottish fjordic sediment, Quatern. Int., 246, 168176, https://doi.org/10.1016/j.quaint.2011.08.016, 2011.

Caracciolo, A., Bali, E., Guðfinnsson, G. H., Kahl, M., Halldórsson, S. A., Hartley, M. E., and Gunnarsson, H.: Temporal evolution of magma and crystal mush storage conditions in the BárðarbungaVeiðivötn volcanic system, Iceland, Lithos, 352/353, 105234, https://doi.org/10.1016/j.lithos.2019.105234, 2020.

Chambers, F. M., Daniell, J. R. G., Hunt, J. B., Molloy, K., and O'Connell, M.: Tephrostratigraphy of An Loch Mór, Inis Oírr, western Ireland: implications for Holocene tephrochronology in the northeastern Atlantic region, Holocene, 14, 703-720, https://doi.org/10.1191/0959683604hl749rp, 2004.

Cole-Dai, J., Ferris, D. G., Lanciki, A. L., Savarino, J., Thiemens, M. H., and McConnell, J. R.: Two likely stratospheric volcanic eruptions in the 1450 s C.E. found in a bipolar, subannually dated 800 year ice core record, J. Geophys. Res., 118, 7459-7466, https://doi.org/10.1002/jgrd.50587, 2013.

Cook, E., Portnyagin, M., Ponomareva, V., Bazanova, L., Svensson, A., and Garbe-Schönberg, D.: First identification of cryptotephra from the Kamchatka Peninsula in a Greenland ice core: Implications of a widespread marker deposit that links Greenland to the Pacific northwest, Quaternary Sci. Rev., 181, 200206, https://doi.org/10.1016/j.quascirev.2017.11.036, 2018.

Coulter, S. E., Pilcher, J. R., Hall, V. A., Plunkett, G., and Davies, S. M.: Testing the reliability of the JEOL FEGSEM $6500 \mathrm{~F}$ electron microprobe for quantitative major element analysis of glass shards from rhyolitic tephra, Boreas, 39, 163-169, https://doi.org/10.1111/j.1502-3885.2009.00113.x, 2010.

Coulter, S. E., Pilcher, J. R., Plunkett, G., Baillie, M., Hall, V. A., Steffensen, J. P., Vinther, B. M., Clausen, H. B., and Johnsen, S. J.: Holocene tephras highlight complexity of volcanic signals in Greenland ice cores, J. Geophys. Res., 117, D21303, https://doi.org/10.1029/2012JD017698, 2012.

Davies, S. M., Elmquist, M., Bergman, J., Wohlfarth, B., and Hammarlund, D.: Cryptotephra sedimentation processes within two lacustrine sequences from west central Sweden, Holocene, 17, 1-13, https://doi.org/10.1177/0959683607076443, 2007.

Davies, S. M., Wastegård, S., Abbott, P. M., Barbante, C., Bigler, M., Johnsen, S. J., Rasmussen, T. L., Steffensen, J. P., and Svensson, A.: Tracing volcanic events in the NGRIP icecore and synchronising North Atlantic marine records during the last glacial period, Earth Planet. Sci. Lett., 294, 69-79, https://doi.org/10.1016/j.eps1.2010.03.004, 2010a.

Davies, S. M., Larsen, G., Wastegård, S., Turney, C. S. M., Hall, V. A., Coyle, L., and Thordarson, T.: Widespread dispersal of Icelandic tephra: how does the Eyjafjöll eruption of 2010 com- 
pare to past Icelandic events?, J. Quaternary Sci., 25, 605-611, https://doi.org/10.1002/jqs.1421, 2010b.

Delmas, R. J., Kirchner, S., Palais, J. M., and Petit, J. R.: 1000 years of explosive volcanism recorded at the South Pole, Tellus B, 44, 335-350, https://doi.org/10.1034/j.1600-0889.1992.00011.x, 1992.

Delwaide, A., Fillion, L., and Payette, S.: Spatiotemporal distribution of light rings in subarctic black spruce, Quebec, Can. J. Forest Res., 21, 1828-1832, https://doi.org/10.1139/x91-252, 1991.

Dunbar, N. W. and Kurbatov, A. V.: Tephrochronology of the Siple Dome ice core, West Antarctica: correlations and sources, Quaternary Sci. Rev., 30, 1602-1614, https://doi.org/10.1016/j.quascirev.2011.03.015, 2011.

Dunbar, N. W., Zielinski, G. A., and Voisins, D. T.: Tephra layers in the Siple Dome and Taylor Dome ice cores, Antarctica: Sources and correlations, J. Geophys. Res., 108, 2374, https://doi.org/10.1029/2002JB002056, 2003.

Dunbar, N. W., Iverson, N. A., Van Eaton, A. R., Sigl, M., Alloway, B. V., Kurbatov, A. V., Mastin, L. G., McConnell, J. R., and Wilson, C. J. N.: New Zealand supereruption provides time marker for the Last Glacial Maximum in Antarctica, Sci. Rep., 7, 12238, https://doi.org/10.1038/s41598-017-11758-0, 2017.

Ernst, G. G. J., Davies, J. P., and Sparks, R. S. J.: Bifurcation of volcanic plumes in a crosswind, Bull. Volcanol., 56, 159-169, https://doi.org/10.1007/BF00279601, 1994.

Esper, J., Büntgen, U., Luterbacher, J., and Krusic, P. J.: Testing the hypothesis of post-volcanic missing rings in temperature sensitive dendrochronological data, Dendrochronologia, 31, 216-222, https://doi.org/10.1016/j.dendro.2012.11.002, 2013.

Esper, J., Büntgen, U., Hartl-Meier, C., Oppenheimer, C., and Schneider, L.: Northern Hemisphere temperature anomalies during the 1450 s period of ambiguous volcanic forcing, Bull. Volcanol., 79, 41, https://doi.org/10.1007/s00445-017-1125-9, 2017.

Fiacco, R. J., Palais, J. M., Germani, M. S., Zielinski, G. A., and Mayewski, P. A.: Characteristics and Possible Source of a 1479 A.D. Volcanic Ash Layer in a Greenland Ice Core, Quaternary Res., 39, 267-273, https://doi.org/10.1006/qres.1993.1033, 1993.

Fiacco, R. J., Thordarson, T., Germani, M. S., Self, S., Palais, J. M., Whitlow, S., and Grootes, P. M.: Atmospheric Aerosol Loading and Transport Due to the 1783-84 Laki Eruption in Iceland, Interpreted from Ash Particles and Acidity in the GISP2 Ice Core, Quaternary Res., 42, 231-240, https://doi.org/10.1006/qres.1994.1074, 1994.

Filion, L., Payette, S., Gauthier, L., and Boutin, Y.: Light rings in subarctic conifers as a dendrochronological tool, Quaternary Res., 26, 272-279, https://doi.org/10.1016/00335894(86)90111-0, 1986.

Gao, C., Robock, A., Self, S., Witter, J. B., Steffensen, J. P., Clausen, H. B., Siggaard-Andersen, M.-L., Johnsen, S. J., Mayewski, P. A., and Ammann, C.: The 1452 or 1453 A.D. Kuwae eruption signal derived from multiple ice core records: Greatest volcanic sulfate event of the past 700 years, J. Geophys. Res., 111, D12107, https://doi.org/10.1029/2005JD006710, 2006.

Gautier, E., Savarino, J., Hoek, J., Erbland, J., Caillon, N., Hattori, S., Yoshida, N., Albalat, E., Albarede, F., and Farquhar, J.: 2600years of stratospheric volcanism through sulfate isotopes, Nat.
Commun., 10, 466, https://doi.org/10.1038/s41467-019-08357$0,2019$.

Grove, J. M.: The Little Ice Age, Routledge, London, UK, 2012.

Gudmundsdóttir, E. R., Eiríksson, J., and Larsen, G.: Identification and definition of primary and reworked tephra in Late Glacial and Holocene marine shelf sediments off North Iceland, J. Quaternary Sci., 26, 589-602, https://doi.org/10.1002/jqs.1474, 2011.

Gudmundsdóttir, E. R., Larsen, G., Björck, S., Ingólfsson, Ó., and Striberger, J.: A new high-resolution Holocene tephra stratigraphy in eastern Iceland: Improving the Icelandic and North Atlantic tephrochronology, Quaternary Sci. Rev., 150, 234-249, https://doi.org/10.1016/j.quascirev.2016.08.011, 2016.

Guillet, S., Corona, C., Stoffel, M., Khodri, M., Lavigne, F., Ortega, P., Eckert, N., Sielenou, P. D., Daux, V., Churakova (Sidorova), O. V., Davi, N., Edouard, J.-L., Zhang, Y., Luckman, B. H., Myglan, V. S., Guiot, J., Beniston, M., Masson-Delmotte, V., and Oppenheimer, C.: Climate response to the Samalas volcanic eruption in 1257 revealed by proxy records, Nat. Geosci., 10, 123-128, https://doi.org/10.1038/ngeo2875, 2017.

Guillet, S., Corona, C., Ludlow, F., Oppenheimer, C., and Stoffel, M.: Climatic and societal impacts of a "forgotten" cluster of volcanic eruptions in 1108-1110 CE, Sci. Rep., 10, 6715, https://doi.org/10.1038/s41598-020-63339-3, 2020.

Hammer, C. U., Clausen, H. B., and Dansgaard, W.: Greenland ice sheet evidence of post-glacial volcanism and its climatic impact, Nature, 288, 230-235, https://doi.org/10.1038/288230a0, 1980.

Harning, D. J., Thordarson, T., Geirsdóttir, Á., Zalzal, K., and Miller, G. H.: Provenance, stratigraphy and chronology of Holocene tephra from Vestfirðir, Iceland, Quat. Geochronol., 46, 59-76, https://doi.org/10.1016/j.quageo.2018.03.007, 2018.

Hartman, L. H., Kurbatov, A. V., Winski, D. A., Cruz-Uribe, A. M., Davies, S. M., Dunbar, N. W., Iverson, N. A., Aydin, M., Fegyveresi, J. M., Ferris, D. G., Fudge, T. J., Osterberg, E. C., Hargreaves, G. M., and Yates, M. G: Volcanic glass properties from 1459 C.E. volcanic event in South Pole ice core dismiss Kuwae caldera as a potential source, Sci. Rep., 9, 14437, https://doi.org/10.1038/s41598-019-50939-x, 2019.

Iverson, N. A., Kalteyer, D., Dunbar, N. W., Kurbatov, A., and Yates, M.: Advancements and best practices for analysis and correlation of tephra and cryptotephra in ice, Quat. Geochronol., 40, 45-55, https://doi.org/10.1016/j.quageo.2016.09.008, 2017.

Jensen, B. J. L., Pyne-O’Donnell, S., Plunkett, G., Froese, D. G., Hughes, P. D .M., Sigl, M., McConnell, J. R., Amesbury, M. J., Blackwell, P. G., van den Bogaard, C., Buck, C. E., Charman, D. J., Clague, J. J., Hall, V. A., Koch, J., Mackay, H., Mallon, G., McColl, L., and Pilcher, J. R.: Transatlantic distribution of the Alaskan White River Ash, Geology, 42, 875-878, https://doi.org/10.1130/G35945.1, 2014.

Koffman, B. G., Kreutz, K. J., Kurbatov, A. V., and Dunbar, N. W.: Impact of known local and tropical volcanic eruptions of the past millennium on the WAIS Divide microparticle record, Geophys. Res. Lett., 40, 4712-4716, https://doi.org/10.1002/grl.50822, 2013.

Koffman, B. G., Dowd, E. G., Osterberg, E. C., Ferris, D. G., Hartman, L. H., Wheatley, S. D., Kurbatov, A. V., Wong, G. J., Markle, B. R., Dunbar, N. W., Kreutz, K. J., and Yates, M.: Rapid transport of ash and sulfate from the 2011 Puyehue-Cordón Caulle (Chile) eruption to 
West Antarctica, J. Geophys. Res.-Atmos., 122, 8908-8920, https://doi.org/10.1002/2017JD026893, 2017.

Kuehn, S. C., Froese, D. G., and Shane, P. A. R.: The INTAV intercomparison of electron-beam microanalysis of glass by tephrochronology laboratories: Results and recommendations, Quatern. Int., 246, 19-47, https://doi.org/10.1016/j.quaint.2011.08.022, 2011.

LaMarche Jr., V. C., and Hirschboeck, K. K.: Frost rings in trees as records of major volcanic eruptions, Nature, 307, 121-126, https://doi.org/10.1038/307121a0, 1984.

Langway Jr., C. C., Osada, K., Clausen, H. B., Hammer, C. U., and Shoji, H.: A 10-century comparison of prominent bipolar volcanic events in ice cores, J. Geophys. Res., 110, 16241-16247, https://doi.org/10.1029/95JD01175, 1995.

Larsen, D. J., Miller, G. H., Geirsdóttir, Á., and Thordarson, T.: A 3000-year varved record of glacier activity and climate change from the proglacial lake Hvítárvatn, Iceland, Quaternary Sci. Rev., 30, 2715-2731, https://doi.org/10.1016/j.quascirev.2011.05.026, 2011.

Larsen, G.: Recent volcanic history of the Veiðivötn fissure swarm, southern Iceland - an approach to volcanic risk assessment, J. Volcanol. Geoth. Res., 22, 33-58, https://doi.org/10.1016/03770273(84)90034-9, 1984.

Larsen, G.: Explosive Volcanism in Iceland: Three Examples of Hydromagmatic Basaltic Eruptions on long Volcanic Fissures within the past 1200 Years, Geophysical Research Abstracts, Vol. 7, 10158, SRef-ID: 1607-7962/gra/EGU05-A-10158, available at: https://meetings.copernicus.org/www.cosis.net/abstracts/ EGU05/10158/EGU05-J-10158.pdf (last access: 7 January 2021), 2005.

Larsen, G. and Eiríksson, J.: Late Quaternary terrestrial tephrochronology of Iceland - frequency of explosive eruptions, type and volume of tephra deposits, J. Quaternary Sci., 23, 109-120, https://doi.org/10.1002/jqs.1129, 2008.

Larsen, G., Gudmundsson, M. T., and Björnsson, H.: Eight centuries of periodic volcanism at the centre of the Iceland hotspot revealed by glacier tephrostratigraphy, Geology, 26, 943-946, https://doi.org/10.1130/00917613(1998)026<0943:ECOPVA>2.3.CO;2, 1998.

Larsen, G., Eiríksson, J., Knudsen, K. L., and Heinemeier, J.: Correlation of late Holocene terrestrial and marine tephra markers, north Iceland: implications for reservoir age changes, Polar Res., 21, 283-290, https://doi.org/10.3402/polar.v21i2.6489, 2002.

Larsen, G., Gudmundsson, M. T., Einarsson, P., and Thordarson, T.: Bárðarbunga, in: Náttúruvá á Íslandi - Eldgos og jarðskjálftar, edited by: Sólnes, S., Sigmundsson, F., and Bessason, B., Viðlagatrygging Íslands/Háskólaútgáfan, Reykjavík, Iceland, 253261, 2013.

Larsen, G., Eiríksson, J., and Gudmundsdóttir, E. R.: Last millennium dispersal of air-fall tephra and ocean-rafted pumice towards the north Icelandic shelf and the Nordic seas, in: Marine Tephrochronology, edited by: Austin, W. E. N., Abbott, P. M., Davies, S. M., Pearce, N. J .G., and Wastegård, S., Geological Society, London, United Kingdom, 113-211, https://doi.org/10.1144/SP398.4, 2014.

Lawson, I. T., Gathorne-Hardy, F. J., Church, M. J., Newton, A. J., Edwards, K. J., Dugmore, A. J., and Einarsson, Á.: Environmental impacts of the Norse settlement: palaeoenvironmen- tal data from Mývatnssveit, northern Iceland, Boreas, 36, 1-19, https://doi.org/10.1111/j.1502-3885.2007.tb01176.x, 2007.

Lawson, I. T., Swindles, G. T., Plunkett, G., and Greenberg, D.: The spatial distribution of Holocene cryptotephras in northwest Europe since $7 \mathrm{ka}$ : implications for understanding ash fall events from Icelandic eruptions, Quaternary Sci. Rev., 41, 57-66, https://doi.org/10.1016/j.quascirev.2012.02.018, 2012.

Legrand, M. R. and Kirchner, S.: Origins and variations of nitrate in south polar precipitation, J. Geophys. Res., 95, 3493-3507, https://doi.org/10.1029/JD095iD04p03493, 1990.

Le Maitre, R. W., Bateman, P., Dudek, A., Keller, J., Lameyre, J., Le Bas, M. J., Sabine, P. A., Schmid, R., Sorensen, H., Streckeisen, A., and Woolley, A. R.: A classification of igneous rocks and glossary of terms, Blackwell, London, United Kingdom, 1989.

MacDonald, G. A. and Katsura, T.: Chemical composition of Hawaiian lavas, J. Petrol., 5, 82-133, https://doi.org/10.1093/petrology/5.1.82, 1964.

Mackie, E. A. V., Davies, S. M., Turney, C. S. M., Dobbyn, K., Lowe, J. J., and Hill, P. G.: The use of magnetic separation techniques to detect basaltic microtephra in last glacial-interglacial transition (LGIT; 15-10 kacal. BP) sediment sequences in Scotland, Scot. J. Geol., 38, 21-30, https://doi.org/10.1144/sjg38010021, 2002.

Marshall, L., Johnson, J. S., Mann, G. W., Lee, L., Dhomse, S. S., Regayre, L., Yoshioka, M., Carslaw, K. S., and Schmidt, A.: Exploring How Eruptive Source Parameters Affect Volcanic Radiative Forcing Using Statistical Emulation, J. Geophys. Res., 124, 964-985, https://doi.org/10.1029/2018JD028675, 2019.

Maselli, O. J., Chellman, N. J., Grieman, M., Layman, L., McConnell, J. R., Pasteris, D., Rhodes, R. H., Saltzman, E., and Sigl, M.: Sea ice and pollution-modulated changes in Greenland ice core methanesulfonate and bromine, Clim. Past, 13, 39-59, https://doi.org/10.5194/cp-13-39-2017, 2017.

McConnell, J. R., Lamorey, G. W., Lambert, S. W., and Taylor, K. C.: Continuous Ice-Core Chemical Analyses Using Inductively Coupled Plasma Mass Spectrometry, Environ. Sci. Technol., 36, 7-11, https://doi.org/10.1021/es011088z, 2002.

McConnell, J. R., Burke, A., Dunbar, N. W., Köhler, P., Thomas, J. L., Arienzo, M. M., Chellman, N. J., Maselli, O. J., Sigl, M., Adkins, J. F., Baggenstos, D., Burkhart, J. F., Brook, E. J., Buizert, C., Cole-Dai, J., Fudge, T. J., Knorr, G., Graf, H. F., Grieman, M. M., Iverson, N., McGwire, K. C., Mulvaney, R., Paris, G., Rhodes, R. H., Saltzman, E. S., Severinghaus, J. P., Steffensen, J. P., Taylor, K. C., and Winckler, G.: Synchronous volcanic eruptions and abrupt climate change similar to $17.7 \mathrm{ka}$ plausibly linked by stratospheric ozone depletion, P. Natl. Acad. Sci. USA, 114, 10035-10040, https://doi.org/10.1073/pnas.1705595114, 2017.

McConnell, J. R., Sigl, M., Plunkett, G., Burke, A., Kim, W. M., Raible, C. C., Wilson, A. I., Manning, J. G., Ludlow, F. M., Chellman, N. J., Innes, H. M., Yang, Z., Larsen, J. F., Schaefer, J. R., Kipfstuhl, S., Mojtabavi, S., Wilhelms, F., Opel, T., Meyer, H., and Steffensen, J. P.: Extreme climate after massive eruption of Alaska's Okmok volcano in 43 BCE and effects on the late Roman Republic and Ptolemaic Kingdom, P. Natl. Acad. Sci. USA, 117, 15443-15449, https://doi.org/10.1073/pnas.2002722117, 2020.

Mekhaldi, F., Muscheler, R., Adolphi, F., Aldahan, A., Beer, J., McConnell, J. R., Possnert, G., Sigl, M., Svensson, A., 
Synal, H.-A., Welten, K. C., and Woodruff, T. E.: Multiradionuclide evidence for the solar origin of the cosmic-ray events of AD 774/5 and 993/4, Nat. Commun., 6, 8611, https://doi.org/10.1038/ncomms9611, 2015.

Miller, G. H., Geirsdóttir, A., Zhong, Y. F., Larsen, D. J., OttoBliesner, B. L., Holland, M. M., Bailey, D. A., Refsnider, K. A., Lehman, S. J., Southon, J. R., Anderson, C., Björnsson, H., and Thordarson, T.: Abrupt onset of the Little Ice Age triggered by volcanism and sustained by sea-ice/ocean feedbacks, Geophys. Res. Lett., 39, L02708, https://doi.org/10.1029/2011GL050168, 2012.

Miyake, F., Nagaya, K., Masuda, K., and Nakamura, T.: A signature of cosmic-ray increase in AD 774-775 from tree rings in Japan, Nature, 486, 240-242, https://doi.org/10.1038/nature11123, 2012.

Miyake, F., Suzuki, A., Masuda, K., Horiuchi, K., Motoyama, H., Matsuzaki, H., Motizuki, Y., Takahashi, K., and Nakai, Y.: Cosmic ray event of AD 774-775 shown in quasi-annual ${ }^{10} \mathrm{Be}$ data from the Antarctic Dome Fuji ice core, Geophys. Res. Lett., 42, 84-89, https://doi.org/10.1002/2014GL062218, 2015.

Monzier, M., Robin, C., and Eissen, J.-P.: Kuwae ( $\approx 1425$ A.D.): the forgotten caldera, J. Volcanol. Geoth. Res., 59, 207-218, https://doi.org/10.1016/0377-0273(94)90091-4, 1994.

Moore, J. C., Narita, H., and Maeno, N.: A continuous 770-year record of volcanic activity from east Antarctica, J. Geophys. Res., 96, 17353-17359, https://doi.org/10.1029/91JD01283, 1991.

Narcisi, B., Petit, J. R., Delmonte, B., Batanova, V., and Savarino, J.: Multiple sources for tephra from AD 1259 volcanic signal on Antarctic ice cores, Quaternary Sci. Rev., 210, 164-174, https://doi.org/10.1016/j.quascirev.2019.03.005, 2019.

Németh, K., Cronin, S. J., and White, J. D. L.: Kuwae Caldera and Climate Confusion, Open Geology Journal, 1, 7-11, https://doi.org/10.2174/1874262900701010007, 2007.

Newhall, C. G. and Self, S.: The volcanic explosivity index (VEI) an estimate of explosive magnitude for historical volcanism, J. Geophys. Res., 87, 1231-1238, 1982.

Óladóttir, B. A., Larsen, G., and Sigmarsson, O.: Holocene volcanic activity at Grímsvötn, Bárdarbunga and Kverkfjöll subglacial centres beneath Vatnajökull, Iceland, Bull. Volcanol., 73, 1187-1208, https://doi.org/10.1007/s00445-011-0461-4, 2011.

Óladóttir, B. A., Thordarson, T., Geirsdóttir, Á., Jóhannsdóttir, G. E., and Mangerud, J.: The Saksunarvatn Ash and the G10ka series tephra. Review and current state of knowledge, Quat. Geochronol., 56, 101041, https://doi.org/10.1016/j.quageo.2019.101041, 2020.

Oppenheimer, C., Wacker, L., Xu, J., Diego Galván, J., Stoffel, M., Guillet, S., Corona, C., Sigl, M., Di Cosmo, N., Hajdas, I., Pan, B., Breuker, R., Schneider, L., Esper, J., Fei, J., Hammond, J. O. S., and Büntgen, U.: Multi-proxy dating the "Millennium Eruption" of Changbaishan to late 946 CE, Quaternary Sci. Rev., 158, 164-171, https://doi.org/10.1016/j.quascirev.2016.12.024, 2017.

Oppenheimer, C., Orchard, A., Stoffel, M., Newfield, T. P., Guillet, S., Corona, C., Sigl, M., Di Cosmo, N., and Büntgen, U.: The Eldgjá eruption: timing, long-range impacts and influence on the Christianisation of Iceland, Climatic Change, 147, 369381, https://doi.org/10.1007/s10584-018-2171-9, 2018.

Owens, M. J., Lockwood, M., Hawkins, E., Usoskin, I., Jones, G. S., Barnard, L., Schurer, A., and Fasullo, J.: The Maunder min- imum and the Little Ice Age: an update from recent reconstructions and climate simulations, J. Sp. Weather Sp. Clim., 7, A33, https://doi.org/10.1051/swsc/2017034, 2017.

Palais, J. M., Taylor, K., Mayewski, P. A., and Grootes, P.: Volcanic ash from the 1362 AD Öræfajökull eruption (Iceland) in the Greenland Ice Sheet, Geophys. Res. Lett., 18, 1241-1244, https://doi.org/10.1029/91GL01557, 1991.

Perkins, M. E., Nash, W. P., Brown, F. H., and Fleck, R. J.: Fallout tuffs of Trapper Creek, Idaho - A record of Miocene explosive volcanism in the Snake River Plain volcanic province, Geol. Soc. Am. Bull., 107, 1484-1506, https://doi.org/10.1130/00167606(1995)107<1484:FTOTCI>2.3.CO;2, 1995.

Perkins, M. E., Brown, F. H., Nash, W. P., Williams, S. K., and McIntosh, W.: Sequence, age and source of silicic fallout tuffs in middle to late Miocene basins of the northern Basin and Range province, Geol. Soc. Am. Bull., 110, 344-360, https://doi.org/10.1130/00167606(1998)110<0344:SAASOS>2.3.CO;2, 1998.

Plummer, C. T., Curran, M. A. J., van Ommen, T. D., Rasmussen, S. O., Moy, A. D., Vance, T. R., Clausen, H. B., Vinther, B. M., and Mayewski, P. A.: An independently dated 2000-yr volcanic record from Law Dome, East Antarctica, including a new perspective on the dating of the 1450s CE eruption of Kuwae, Vanuatu, Clim. Past, 8, 1929-1940, https://doi.org/10.5194/cp8-1929-2012, 2012.

Plunkett, G. and Pilcher, J. R.: Defining the potential source region of volcanic ash in northwest Europe during the Mid- to Late Holocene, Earth-Sci. Rev., 179, 20-37, https://doi.org/10.1016/j.earscirev.2018.02.006, 2018.

Plunkett, G., Sigl, M., Pilcher, J. R., McConnell, J. R., Chellman, N., Steffensen, J. P., and Büntgen, U.: Smoking guns and volcanic ash: the importance of sparse tephras in Greenland ice cores, Polar Res., 39, 3511, https://doi.org/10.33265/polar.v39.3511, 2020.

Pollard, A. M., Blockley, S. P. E., and Ward, K. R.: Chemical alteration of tephra in the depositional environment: theoretical stability modelling, J. Quaternary Sci., 18, 385-394, https://doi.org/10.1002/jqs.760, 2003.

Robin, C., Monzier, M., and Eissen, J.-P.: Formation of the midfifteenth century Kuwae caldera (Vanuatu) by an initial hydroclastic and subsequent ignimbrite eruption, B. Volcanol., 56, 170-183, https://doi.org/10.1007/BF00279602, 1994.

Robock, A.: Volcanic eruptions and climate, Rev. Geophys., 38, 191-219, https://doi.org/10.1029/1998RG000054, 2000.

Ruth, U., Wagenbach, D., Steffensen, J. P., and Bigler, M.: Continuous records of microparticle concentration and size distribution in the central Greenland NGRIP ice core during the last glacial period, J. Geophys. Res., 108, 4098, https://doi.org/10.1029/2002JD002376, 2003.

Salzer, M. W. and Hughes, M. K.: Bristlecone pine tree rings and volcanic eruptions over the last $5000 \mathrm{yr}$, Quaternary Res., 67, 57-68, https://doi.org/10.1016/j.yqres.2006.07.004, 2007.

Schneider, L., Smerdon, J. E., Büntgen, U., Wilson, R. J. S., Myglan, V. S., Kirdyanov, A. V., and Esper, J.: Revising midlatitude summer temperatures back to A.D. 600 based on a wood density network, Geophys. Res. Lett., 42, 4556-4562, https://doi.org/10.1002/2015GL063956, 2015.

Schurer, A. P., Hegerl, G. C., Mann, M. E., Tett, S. F. B., and Phipps, S. J.: Separating Forced from Chaotic Climate Vari- 
ability over the Past Millennium, J. Climate, 26, 6954-6973, https://doi.org/10.1175/JCLI-D-12-00826.1, 2013.

Schurer, A. P., Tett, S. F. B., and Hegerl, G. C.: Small influence of solar variability on climate over the past millennium, Nat. Geosci. 7, 104-108, https://doi.org/10.1038/ngeo2040, 2014.

Sigl, M., McConnell, J. R., Layman, L., Maselli, O., McGwire, K., Pasteris, D., Dahl-Jensen, D., Steffensen, J. P., Vinther, B., Edwards, R., Mulvaney, R., and Kipfstuhl, S.: A new bipolar ice core record of volcanism from WAIS Divide and NEEM and implications for climate forcing of the last 2000 years, J. Geophys. Res., 118, 1151-1169, https://doi.org/10.1029/2012JD018603, 2013.

Sigl, M., McConnell, J. R., Toohey, M., Curran, M., Das, S. B., Edwards, R., Isaksson, E., Kawamura, K., Kipfstuhl, S., Krüger, K., Layman, L., Maselli, O., Motizuki, Y., Motoyama, H., Pateris, D. R., and Severi, M.: Insights from Antarctica on volcanic forcing during the Common Era, Nat. Clim. Change, 4, 693-697, https://doi.org/10.1038/nclimate2293, 2014.

Sigl, M., Winstrup, M., McConnell, J. R., Welten, K. C., Plunkett, G., Ludlow, F., Büntgen, U., Caffee, M., Chellman, N., Dahl-Jensen, D., Fischer, H., Kipfstuhl, S., Kostick, C., Maselli, O. J., Mekhaldi, F., Mulvaney, R., Muscheler, R., Pasteris, D. R., Pilcher, J. R., Salzer, M., Schüpbach, S., Steffensen, J. P., Vinther, B. M., and Woodruff, T. E.: Timing and climate forcing of volcanic eruptions for the past 2,500 years, Nature, 523, 543-549, https://doi.org/10.1038/nature14565, 2015.

Sigl, M., Fudge, T. J., Winstrup, M., Cole-Dai, J., Ferris, D., McConnell, J. R., Taylor, K. C., Welten, K. C., Woodruff, T. E., Adolphi, F., Bisiaux, M., Brook, E. J., Buizert, C., Caffee, M. W., Dunbar, N. W., Edwards, R., Geng, L., Iverson, N., Koffman, B., Layman, L., Maselli, O. J., McGwire, K., Muscheler, R., Nishiizumi, K., Pasteris, D. R., Rhodes, R. H., and Sowers, T. A.: The WAIS Divide deep ice core WD2014 chronology Part 2: Annual-layer counting (0-31 ka BP), Clim. Past, 12, 769786, https://doi.org/10.5194/cp-12-769-2016, 2016.

Slawinska, J. and Robock, A.: Impact of Volcanic Eruptions on Decadal to Centennial Fluctuations of Arctic Sea Ice Extent during the Last Millennium and on Initiation of the Little Ice Age, J. Climate, 31, 2145-2167, https://doi.org/10.1175/JCLI-D-160498.1, 2018.

Smith, V. C., Costa, A., Aguirre-Díaz, G., Pedrazzi, D., Scifo, A., Plunkett, G., Poret, M., Tournigand, P.-Y., Miles, D., Dee, M. W., McConnell, J. R., Sunyé-Puchol Dávila Harris, P., Sigl, M., Pilcher, J. R., Chellman, N., and Gutiérrez, E.: The magnitude and impact of the 431 CE Tierra Blanca Joven eruption of Ilopango, El Salvador, P. Natl. Acad. Sci. USA, https://doi.org/10.1073/pnas.2003008117, 2020.

Stoffel, M., Khodri, M., Corona, C., Guillet, S., Poulain, V., Bekki, S., Guiot, J., Luckman, B. H., Oppenheimer, C., Lebas, N., Beniston, M., and Masson-Delmotte, V.: Estimates of volcanic-induced cooling in the Northern Hemisphere over the past 1,500 years, Nat. Geosci., 8, 784-788, https://doi.org/10.1038/ngeo2526, 2015.

Streeter, R. and Dugmore, A. J.: Late-Holocene land surface change in a coupled social-ecological system, southern Iceland: a crossscale tephrochronology approach, Quaternary Sci. Rev., 86, 99114, https://doi.org/10.1016/j.quascirev.2013.12.016, 2014.

Sun, C., Plunkett, G., Liu, J., Zhao, H., Sigl, M., McConnell, J. R., Pilcher, J. R., Vinther, B., Steffensen, J. P., and Hall,
V.: Ash from Changbaishan Millennium eruption recorded in Greenland ice: Implications for determining the eruption's timing and impact, Geophys. Res. Lett., 41, 694-701, https://doi.org/10.1002/2013GL058642, 2014.

Thórarinsson, S.: The Öræfajökull Eruption of 1362, Acta Nat. Isl., 2, 1-99, 1958.

Thordarson, T. and Larsen, G.: Volcanism in Iceland in historical time: Volcano types, eruption styles and eruptive history, J. Geodyn., 43, 118-152, https://doi.org/10.1016/j.jog.2006.09.005, 2007.

Thordarson, T., Miller, D. J., Larsen, G., Self, S., and Sigurdsson, H.: New estimates of sulfur degassing and atmospheric mass-loading by the 934 AD Eldgjá eruption, Iceland, J. Volcanol. Geoth. Res., 108, 33-54, https://doi.org/10.1016/S03770273(00)00277-8, 2001.

Toohey, M. and Sigl, M.: Volcanic stratospheric sulfur injections and aerosol optical depth from 500 BCE to 1900 CE, Earth Syst. Sci. Data, 9, 809-831, https://doi.org/10.5194/essd-9-809-2017, 2017.

Toohey, M., Krüger, K., Sigl, M., Stordal, F., and Svensen, H.: Climatic and societal impacts of a volcanic double event at the dawn of the Middle Ages, Clim. Change, 136, 401-412, https://doi.org/10.1007/s10584-016-1648-7, 2016.

Toohey, M., Krüger, K., Schmidt, H., Timmreck, C., Sigl, M., Stoffel, M., and Wilson, R.: Disproportionately strong climate forcing from extratropical explosive volcanic eruptions, Nat. Geosci., 12, 100-107, https://doi.org/10.1038/s41561-018-0286-2, 2019.

Vakhrameeva, P., Portnyagin, M., Ponomareva, V., Abbott, P. M., Repkina, T., Novikova, A., Koutsodendris, A., and Pross, J.: Identification of Icelandic tephras from the last two millennia in the White Sea region (Vodoprovodnoe peat bog, northwestern Russia), J. Quaternary Sci., 35, 493-504, https://doi.org/10.1002/jqs.3190, 2020.

Vinther, B. M., Clausen, H. B., Johnsen, S. J., Rasmussen, S. O., Andersen, K. K., Buchardt, S. L., Dahl-Jensen, D., Seierstad, I. K., Siggaard-Andersen, M.-L., Steffensen, J. P., Svensson, A., Olsen, J., and Heinemeier, J.: A synchronized dating of three Greenland ice cores throughout the Holocene, J. Geophys. Res., 111, D13102, https://doi.org/10.1029/2005JD006921, 2006.

Watson, E. J., Swindles, G. T., Savov, I. P., Lawson, I. T., Connor, C. B., and Wilson, J. A.: Estimating the frequency of volcanic ash clouds over northern Europe, Earth Planet. Sci. Lett., 460, 41-49, https://doi.org/10.1016/j.eps1.2016.11.054, 2017.

Wilson, R., Anchukaitis, K., Briffa, K. R., Büntgen, U., Cook, E., D’Arrigo, R., Davi, N., Esper, J., Frank, D., Gunnarson, B., Hegerl, G., Helama, S., Klesse, S., Krusic, P. J., Linderholm, H. W., Myglan, V., Osborn, T. J., Rydval, M., Schneider, L., Schurer, A., Wiles, G., Zhang, P., and Zorita, E.: Last millennium northern hemisphere summer temperatures from tree rings: Part I: The long term context, Quaternary Sci. Rev., 134, 1-18, https://doi.org/10.1016/j.quascirev.2015.12.005, 2016.

Witter, J. B. and Self, S.: The Kuwae (Vanuatu) eruption of AD 1452: potential magnitude and impact and volatile release, B. Volcanol., 69, 301-318, https://doi.org/10.1007/s00445-0060075-4, 2007.

Yamaguchi, D. K.: New tree-ring dates for recent eruptions of Mount St. Helens, Quaternary Res., 20, 246-250, https://doi.org/10.1016/0033-5894(83)90080-7, 1983. 
Zanolini, F., Delmas, R. J., and Legrand, M.: Sulphuric and nitric acid concentrations and spikes along a 200m deep ice core at D 57 (Terre Adélie, Antarctica), Ann. Glaciol., 7, 70-75, https://doi.org/10.3189/S0260305500005930, 1985.

Zielinski, G. A.: Stratospheric loading and optical depth estimates of explosive volcanism over the last 2100 years derived from the Greenland Ice Sheet Project 2 ice core, J. Geophys. Res., 100, 20937-20955, https://doi.org/10.1029/95JD01751, 1995.
Zielinski, G. A., Mayewski, P. A., Meeker, L .D., Whitlow, S., Twickler, M. S., Morrison, M., Meese, D. A., Gow, A. J., and Alley, R. B.: Record of Volcanism Since 7000 B.C. from the GISP2 Greenland Ice Core and Implications for the Volcano-Climate System, Science, 264, 948-952, https://doi.org/10.1126/science.264.5161.948, 1994. 